\title{
Rahvapillipärandi säilitamine Eestis ja välismaal
}

\begin{abstract}
Ain Haas
Teesid: 20. sajandi keskpaigaks olid vanad rahvapillid eesti kultuurist kadunud. Mängiti moodsaid rahvusvahelisi pille, eriti lõõtspilli ja kitarri. Artikkel käsitleb vanade rahvapillide (eriti kandle, torupilli ja Hiiu kandle) tagasitulekut. Nende traditsioonide taaselustamine on Eestis kaugemale jõudnud ja paremini juurdunud muusikakoolide ja muuseumide abil, aga ka väliseestlaste seas on teatud määral täheldatav samasugune kulgemine. Mõlemal pool on suurt rolli mänginud esivanemate kadunud kultuurist vaimustatud eestvedajad ja võtmeisikud. Huvi kadunud pillide vastu on ilming vastupanust moodsa ühiskonna homogeensusele.

Linnastumine, rahvusvahelised kontaktid ja moodne tehnoloogia tõid suuresti kaasa rahvamuusika populaarsuse languse möödunud sajandil, kuid samad tegurid on viimasel ajal osutunud väga olulisteks abivahenditeks traditsioonide taaselustamisel.
\end{abstract}

Märksõnad: Hiiu kannel, kannel, rahvapillid, torupill

\section{Sissejuhatuseks}

Pillimäng on muinasajast alates olnud eestlaste rahvakultuuripärandi püsiv ja tähtis osa, aga sajandite jooksul on moes olnud erinevad pillid. Käesolevas artiklis käsitletatakse kolme rahvapilli, mis on seotud ürgvanade traditsioonidega. Kannel, torupill ja Hiiu kannel on kõik kaua olnud eestlaste rahvakultuuris kesksel kohal. Need muusikariistad on seotud esivanemate kommete ja uskumustega, nad on arenenud omapäraste kujudeni (s.t on ainulaadsed või omavad samasuguseid vorme ainult naabermaades), nende populaarsus on vahepeal drastiliselt langenud, aga viimasel ajal on aset leidnud märkimisväärne tagasitulek. Artiklis analüüsitakse iga pilli päritolu, ehitusviisi, kasutust ja levikut, võrreldakse erinevaid ajastuid ning olukorda kodumaal ja väljapool. Kõige lõpuks käsitletatakse moodsa ühiskonna arenguga seotud tegureid, mis esialgu olid rahvapillitraditsioonide säilitamise seisukohalt kahjulikud, hiljem aga kasulikud. 


\section{Kannel}

Kannel on tõenäoliselt eestlaste kõige vanem keelpill. Siin käsitletakse peamiselt neid kandletüüpe, mis olid enne 20. sajandi algust välja kujunenud ja hästi juurdunud rahvamuusikute seas. Arvestades tüpoloogiaga, mis on esitatud Tõnuristi jt raamatus (2008: 72-88), on tegemist kahe tüübiga: väikekannel (mis hõlmab ka setu varianti) ja uuema kandle variandid - välja arvatud rahvakannel (kolme põhiakordi keelterühmaga), mis pole kuigi vana variant. Välja jäävad veel saate- ehk akordkannel (viisikeelteta) ja kromaatiline kannel (kõigi pooltoonidega), mis on ka ilmunud alles 20. sajandil.

\section{Väikekandle algupära}

Arhailist tüüpi kannel (väikekannel, vana kannel) on õõnestatud ühest puupakust (vanasti ristkirve abil, tänapäeval puuri ja peitliga). Juurdelisatud kõlalaud ehk kaas on tavaliselt okaspuust ja kinnitatud raudnaelakeste, puupulgakeste või liimiga. Kõlalaual on tavaliselt ümmargune või ristikujuline kõlaauk (resonantsava), nagu põhjanaabrite (soomlaste ja karjalaste) kantelel, või mitmest väikesest august koosnev muster (nt rist sõori sees). Harvem on näha kuue kiirega lillekujulist päikeseratast, mis on tavalisem lõunanaabrite (lätlaste ja leedulaste) pillidel. Muuseumieksemplaride seas on 6-12 keelt enamasti terasest, vahel vasksulamist, ühel juhtumil jõhvist (võib-olla tehti vanasti kandlekeeli ka sooltest, nagu Hiiu kandlel). Võib arvata, et vanasti leidus ka viie- või isegi nelja-keelelisi kandleid, nagu naabermaade pisimatel pillidel. Vanades kandleteemalistes rahvalauludes mainitakse keelte arvu Jakob Hurda kogus ainult ühel korral 39 laulu seas - tegemist on kuue keelega (Eisen jt 1926: 1). Arhailise kandle keeled paiknevad lehvikukujuliselt, mitte rööbiti, ja keelte vahed on keerpulkade/virblite juures suuremad kui põikpulga ehk keeltehoidja juures.

Vana kandle kuju meenutab inimese labajalga, kuna keeled on erineva pikkusega. Setu kandlel on keerpulkade juures pillikorpuse laba-nimeline pikendus, mis on kasulik käe toetamiseks, kui pill asetseb külgepidi istuva mängija reite peal ja mängitakse rütmilist tantsusaadet. Mujal Eestis on pill olnud rohkem meloodia mängimiseks, kusjuures pilli tagakülg toetub reite või laua vastu.

Pilli nimetuse seletuseks on pakutud mitu võimalust nt soome tüvest, mis tähendab kansi 'kaas/kaane' (kõlalaud) või kanta 'kand' (kolju, kõlakasti kõrgendus põikpulga hoidmiseks) ja eksootilisemaid laensõnu (Haas 2001: 216). Kõige tõenäolisem seletus on aga nähtavasti see, et sõna 'kannel' tuleneb ole- 
tatavast ürgbalti või -slaavi sõnast *gantli 'keelpill' (Tõnurist 1977a: 153; vt ka Itkonen \& Kulonen 1992: 301-302). Kõik kandlerahvaste nimetused on üsna sarnased: nt soome keeles kantele, karjala kandeleh, vepsa kandel, eesti kannel või vanamoelisem kandel, liivi kāndla, läti kokle, leedu kanklès, vene gusli ja poola gęśle (hääldatakse nagu genšle). Eriti viimane tundub olevat vahepealne vorm, mis oleks võinud olla ka teiste nimetuste allikaks.

Pilli vanuse kohta Eestis pole täpsemaid andmeid. Esimene kirjalik viide pärineb aastast 1579 Tallinna raekoja kohtuprotokollist, kui mittesaksa lihunike seltskonnas löödi kellelegi pähe mittesaksa harfiga, s.t kandlega (Arro 1931: 175; Tampere 1975: 33). Autori arvates on kannel arenenud Põhja-Euroopa lüürast rauaajal või keskajal. Pole tõenäoline, et sellist pilli õonestati puupakust enne raudriistade kasutuselevõtmist. Nii Gdanskist kui ka Novgorodist on leitud kandlekujulise lüüra jäänuseid (käeauguga pille), 4-9? keelega, dateeritud ajavahemikku 1000-1400. Lüürat mängiti, hoides pilli vertikaalselt põlvede vahel, mitte süles. Vanade joonistuste/maalide järgi teame, et vasak käsi ulatus pilli tagaküljelt läbi käeaugu (mänguava) keelte vastu ja parem käsi hoidis plektronit keelte siblimiseks. Autori arvates võis kannel tekkida siis, kui keegi, kes ei austanud lüüraga seotud traditsioone, leidis et pillimäng vertikaalses asendis on liiga kohmakas, ja pani pilli horisontaalsesse asendisse. Kui mõlemad käed on keelte peal, pole käeauku enam vaja. Gdansk ja Novgorod olid rahvusvahelised kaubanduskeskused, kus selline kombemuutus võis kergesti tekkida, kui mõni võhik võttis kätte võõra rahva pilli ega teadnud või hoolinud traditsioonilisest mänguviisist suurt midagi. On märkimisväärne, et Novgorodist on leitud nii käeauguga kui ka käeauguta pille, nii et üleminek võis toimuda just seal kandis, kus läänemeresoome, slaavi, ja skandinaavia kauplejad kokku tulid. Skandinaavlastel ja sakslastel oli ka oma lüüra, aga see oli sümmeetriline, s.t võrdsete keelepikkustega. Selle kuju ei sarnanenud eestlaste vanale kandlele ja naaberrahvaste keelpillidele, küll aga Eestisse tulnud rannarootslaste Hiiu(rootsi) kandlele, mida mängitakse poognaga. Kandle võimalikku arengut lüürast arutatakse mitmes artiklis (Tõnurist 1977a; Povetkin 1989, 2007; Haas 2001; Tëmkin 2004). Foto 1 näitab lüüra, kandle, ja Hiiu(rootsi) kandle sarnasusi.

Häälestuse suhtes leidub andmeid ainult ühe muuseumieksemplari kohta: Kaarmast pärit kuue-keeleline kannel (Eesti Rahva Muuseumi kataloogi kirjeldus eseme A 292:2 kohta, nagu nr 5 fotol 1), tehtud 1890. aastal. (Sama pill võeti eeskujuks, kui Tallinna Klaverivabrik tootis poolteist tuhat väikekannelt aastail 1990-1997.) Kõige pikema keele toon oli madal G, siis C, D, E, F, G. Järelikult on häälestus samasugune kui soome viie keelega kandlel, aga juurde on tulnud madal burdoonkeel (G). Tänapäeval eelistavad kuue-keelelise kandle mängijad sellist häälestust: C, D, E, F, G, A (kui pill on C-duuris). 


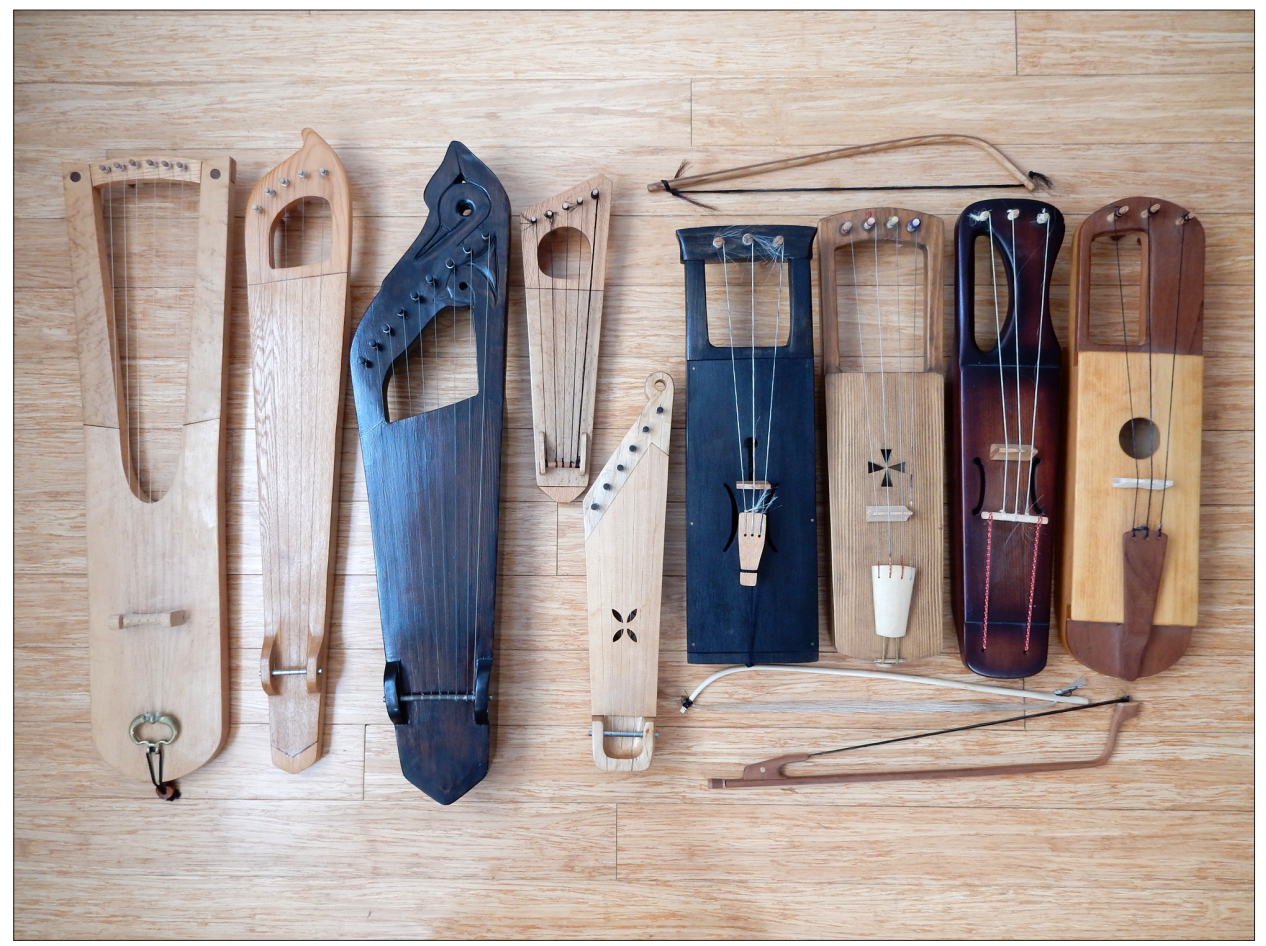

Foto 1. Kirde-Euroopa keelpillide rekonstruktsioonid. Vasakult: (1) Oberflachti lü̈̈ra (Saksamaa, 6. sajand); (2) Slovisha gusli (Novgorod, Venemaa, 11. sajand); (3) Nerevski gusli (Novgorod, Venemaa, 13. sajamd); (4) Gdanski lü̈rra (Poola, 13. sajand); (5) Kaarma kannel (Saaremaa, 1890); (6) Noarootsi talharpa (umbes 1755); (7) Vormsi talharpa; (8) Karjala jouhikko (Loode-Venemaa); (9) moodne jouhikko (Soome). Nr-d 1-6 tegi Ain Haas Indianapolises (USA); 7-9 on tehtud Soomes. Ain Haasa foto 2015.

See võimaldab mängida rohkem viise. Vanade noodistuste ja helisalvestuste põhjal võib ka oletada, et häälestus oli samamoodi diatooniline, vahel mõne madala burdoonkeelega, aga pole alati selge, kas mängija kannel oli arhailist tüüpi või moodne. Katrin Valk (2005: 39-40) analüüsis Armas Otto Väisäneni 1913. aastal vaharullidele tehtud helisalvestusi Setumaa retkedelt ja avastas, et mõlemad mainitud heliread olid tol ajal kasutusel 6-7 keelega kanneldel. Oli ka teisi variante, näiteks üks burdoonkeel (C-duuris oleks see madal G) või kaks (ka veelgi madalam C), ja minoorne häälestus $\mathrm{C}, \mathrm{D}, \mathrm{Eb}, \mathrm{F}, \mathrm{G}$. 


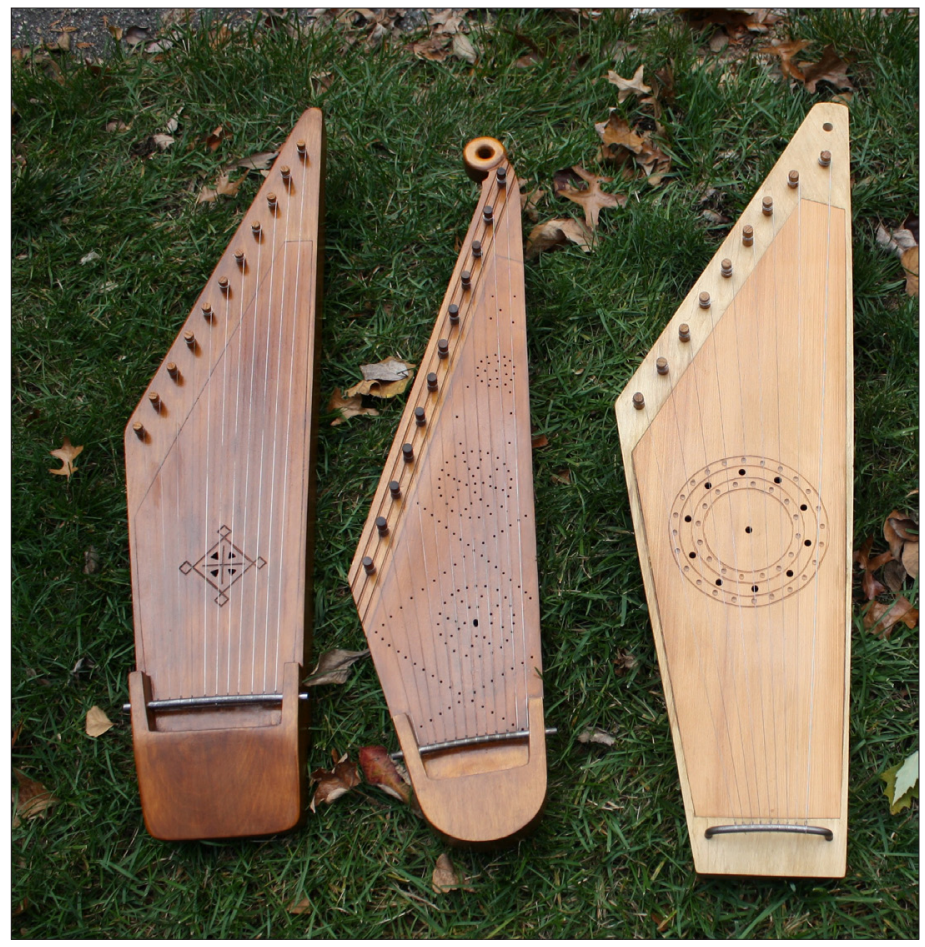

Foto 2. Autori tehtud jäljendeid muuseumieksemplaridest. Vasakult: 11keeleline teadmata päritoluga kannel, 12keeleline Vändra kannel (originaal tehtud 1804. aastal), üheksakeeleline Rõngu "vaimude peletamise kannel" (umbes 1820. aastal tehtud originaalil oli 8 keelt). Ain Haasa foto 2012.

\section{Suurte kannelde tekkimine}

Paarsada aastat tagasi hakkasid eesti talupojad mängima nn külakandlel, mis on arenenud Kesk-Euroopa (arvatavasti Saksa) sõrmlauata tsitrist, aga suuremate keeltevahetega, nii et saab rakendada vana kandlemängu katmisja noppimistehnikat (vt allpool) ja loobuda saksapärasest plektronimängust. Sellise pilli kuju on tuttav ka ameeriklastele, sest nende autoharf on sama päritoluga. Külakandle 15-20 keelega on võimalik mängida keerulisemaid viise (suurema noodiulatusega). Selline keeltearv tekitab nii suurt pinget, et õonestatud pill läheks kergesti katki. Lahendus seisneb laudade liimimises tugeva raami ümber. Eriti Lätis ja Leedus on sellise moodsa konstruktsiooniga pillid 


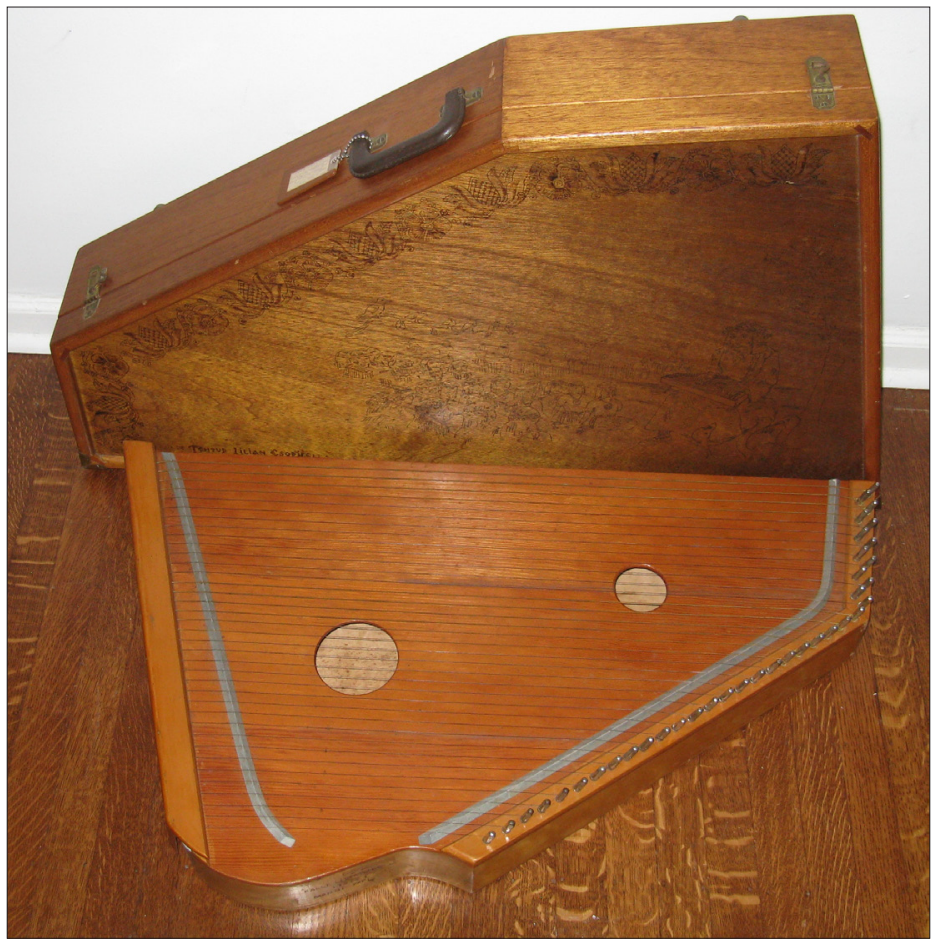

Foto 3. Valter Raudkivi 37keeleline kannel, mille ta tegi Baltimore'is (USA) 1967. aastal oma tütrele Lilian Esopile. Kandlekasti kaanel on joonistus Vanemuise kandlemängust lindude-loomade ees. Raudkivi võttis samasuguse 1935. aastal enda tehtud 34keelelise kandle kaasa, kui põgenes sõja lõpus Viru-Jaagupist. Ain Haasa foto 2014.

tihti ikkagi vana kandle kujuga, aga Eestis kadus traditsiooniline labajalakuju. Selle asemele tuli trapetsikujuline kannel või harfinetikujuline kannel (mis sarnaneb klaverikeelte raamiga, kuna üks külg on S-tähe moodi kaardus).

Hiljem tekkis mitu veelgi suuremat kandletüüpi. Suur diatooniline viisikannel (ka simmel või simbel (vt foto 3) on tavaliselt 25-35 keelega, nii et saab mitmes oktaavis mängida meloodiat ühe käega ja saadet teise käega. Päkarauakandlel mängitakse pöidla ümber pandud spiraalse metallplektroniga. Selline riist on pärit arvatavasti Saksa tsitri (sõrmlauata) või Alpi tsitri (sõrmlauaga) mängust. Selle pilli topeltkeeled on tihti oktaavis, nii et igas paaris on üks keel palju lühem kui teine. Päkaraua ja topeltkeelte tõttu on selline pill väga vali, mis on tantsu saateks hea. 
Keelte arv kasvas ka väikestel kanneldel, vahel isegi olemasolevatel pillidel. Seda on selgesti näha Vigala kandlel (ERM A566: 497), mille küljele on nikerdatud aastaarv 1818. Üheksa keerpulga augud on sirges joones, aga kümnes auk on ilmselt juurde tehtud, see kaldub teiste joonest kõrvale ja paikneb pilli äärele ootamatult lähedal. Pilli ilu on ohverdatud madala burdoonkeele lisamiseks. Noarootsi kandle puhul (N104374, tehtud umbes 1800. aastal), mis on Stockholmis muusikamuuseumis, on hullematki näha. Tollel pillil oli algupäraselt kümme keelt. Keerpulkade augud pandi kunagi puutükkidega kinni ja siis puuriti 12 uut auku. Laiema noodiulatusega saab ju huvitavamaid valsse, reinlendereid, polkasid ja muid uusi tantse esitada.

\section{Kandle kasutamine vanal ajal}

Sellised väikekandle kohandamise katsed näitavad, et pilli funktsioon oli muutumas. Kirjapanekud vana pilli kasutuse kohta on väga haruldased, aga leidub märkmeid, et vanasti mängiti kannelt haige rahustamiseks või ravimiseks (Veske 1877), kurjade vaimude peletamiseks magamamineku ajal (ERM-i kataloogi kirjeldus Rõngu kandle A279: 65 kohta; 8-k. "ebausu" [paganlik] pill pärineb umbes aastast 1820), südamete soojaks tegemiseks pulmades ning teistel pidudel (ERMi kataloogi kirjeldus Irboska/Pokolodova kandle A176: 27 kohta; pill tehtud umbes 1820) ning leinajate lohutamiseks matustel (SuureJaani rahvalaulu järgi, Veske 1879). Valk (2005: 34-35) tsiteerib Väisäneni 1913. aasta Setumaa retkedelt korjatud märkmeid sellistest uskumustest. Soome Kandlemuuseumis (Jyväskyläs) on Tartust toodud vana kannel, mis olevat kuulunud kuulsale eesti runolauljale [regilauljale]. Pole selge, kas see oli talupoja või linnamuusiku pill, aga väikekandle piiratud keeltearv sobib hästi regilaulude mängimiseks või saatmiseks.

Selliste ritualistlike tavade jaoks kõlbab suhteliselt vaikse hääle ja väikse noodiulatusega pill küll. Aga tantsijate saatmiseks külasimmanil on moodne suurkannel parem oma suurema kõlakasti, jämedamate keelte ja bassisaate tõttu. Viiul ja lõõtspill sobivad selleks veel paremini, kuna need pillid on valjemad, nende hääleshoidmine on lihtsam ja nendega on kergem teha duurivahetusi, mis teeb viisi kordamise huvitavamaks. 20. sajandi alguseks oli väikekannel taandumas uute pillitüüpide ees. Viimased eksemplarid korjati muuseumidesse peamiselt Setumaalt ja Saaremaalt - marginaalsed maakonnad, kus rahvusvaheliste kontaktide, linnastumise ja uue tehnoloogia mõjud polnud nii tugevad kui mujal Eestis. Möödunud sajandi keskpaigaks olid eesti rahvamuusikud jätnud väikekandle täiesti kõrvale. 


\section{Väikekandle tegemine}

Unustatud pilli tagasitulek algas 1970. aastatel välismaal. Esimeseks eestvedajaks sai Andres Peekna (1937-2014), elukutselt füüsik ja mehhaanikainsener. Nagu ta seletas intervjuus (1995), hakkas ta huvi tundma väikekandle vastu, kui ameerika soost abikaasa küsis temalt: "Missugune eestlane sa siis oled, kui sul pole isegi kannelt?" Uurides kandle ajalugu oli Peekna avastanud arhailise tüübi mitme allika kaudu: Andersson (1930), Arro (1931), Tõnuristi väitekiri, Jansons (1965) ja välisläti koklemeister Konstantins Dravnieks, kellega ta tutvus Milwaukee kandis. Peekna otsustas, et sellise pilli meisterdamine ja mängimine võimaldaks tal teha ainulaadse panuse rahvakultuuripärandi säilitamiseks. Kui ta kolis mõneks aastaks Mississippi osariiki, kus polnud läheduses teisi eestlasi, oli tal raske leida tegevusi, millede abil oleks võimalik oma lastele õpetada midagi eesti kultuurist, aga kandlemäng sobis selleks küll. Peekna isa, kes ei pääsenud sõja lõpul Läände, saatis andmeid ja fotosid kahe pilli kohta, mis pakkusid erilist huvi: 6-keeleline Kaarma kannel (ERM A292: 2, tehtud 1890, nr 5 fotol 1) ja 12-keeleline Vändra kannel (joonis 1 ja foto 2 keskel: Tallinna Muusikamuuseumis on 1920. aastatel tehtud jäljend; 1804. aastal valmistatud originaal on kadunud). Rakendades oma füüsikuoskusi arvestas uus kandlemeister, et just nendesugustel pillidel peaksid keelte pinged olema enamvähem ühtlased, mis on tähtis heade kõlade saavutamiseks. Ta otsustas, et Kaarma kandle jäljend võiks olla originaalist natuke pikem (52 cm, originaali 49 asemel), kui panna teraskeeled G-duuri, milline häälestus sobiks ka Vändra kandlele ja oleks kooskõlas paljude rahvaviiside noodistustega. (See osutus heaks valikuks ka selle tõttu, et tema ansamblisse tulnud torupill oli samuti G-duuris.) Kui Peekna kolis pärast Chicagosse, mängis ta esialgu perekonna kandleansamblis, ja hiljem juhatas rahvapilliansamblit Tuuletargad (Wind Wizards).

Peekna tegi kanneldega teaduslikke eksperimente. Proovis vaseberülliumi sulamist tehtud keeli (hambaarsti traadist) ja leidis, et see materjal peab pingele vastu palju paremini kui puhas vask ja annab ilusa maheda heli, mis sobib eriti aeglaste viiside jaoks. Traadiga seotud rippuvasse ämbrisse valas ta aeglaselt vett, et teha selgeks, kui suurt kaalu terasest või vasesulamist traat hoiab enne katkemist - nii selgus, kui suur pinge võib teatud keeletüübil olla. Teadusliku valemiga tegi ta selgeks, missugune on sobiv pinge teatud tooni jaoks, et keel kõlaks hästi ega läheks ülepingutamisel katki. Akustikalaboratooriumis (televisiooni holograafia aparatuuriga) uuris ta kõlaaukude panust kandle kõlale, ja jõudis järeldusele, et mitu väikest auku on parem kui üks suur. Teine insener, välislätlane Konstantins Dravnieks, oli uurinud erinevate puuliikide sobivust keerpulkade tegemiseks, ja uurimistulemuste põhjal 
otsustas Peekna, et troopilisest cocobolost pulgad peavad kõige paremini vastu niiskuse- ja temperatuurivahetustele, tagades sellega stabiilseima häälestuse (selle puu saepuru tekitab aga rasket allergilist reaktsiooni, kui meister hingab seda kopsudesse).

Peekna käis autoriga vanu kandleid uurimas mitmes Eesti muuseumis Eesti Rahva Muuseumis (Tartus), Eesti Teatri- ja Muusikamuuseumis (Tallinnas) ja Ajaloomuuseumis (Tallinnas). Autor on ka uurinud vanu eesti kandleid Järvamaa Muuseumis (Paides), Soome Rahvusmuuseumis (Helsingis) ja Rootsi Lavakunstimuuseumis (Stockholmis). Kandlejoonistusi, teadmisi ja kogemusi jagati nendega, kes tundsid huvi kandletegemise vastu. Silmapaistvamate meistrite seas on Tiit Kao ja Henn Kurvits (Toronto kandis Kanadas), Toivo Tähemaa (Tallinnas), Indrek Roosi (alguses Tallinnas Vanalinna Muusikakooli puidutöökojas, hiljem Järvamaal ja Viljandis), Rait Pihlap (Kandlekoja meister Raplamaal), Mart Aardam (Saaremaal), Mihkel Soon (Võrumaal), Rein Reinpõld (Pilliaida meister Viljandimaal) ja Raivo Sildoja (alguses Viljandis, praegu Mooste Rahvamuusikakoolis). Autor on ise teinud umbes 40 väikekannelt või sarnast pilli (Indianapolises, USA-s).

Eestis, Ameerikas ja Kanadas on sellised meistrid korraldanud kandletegemiskursusi ja laagreid, kus asjahuvilised saavad ise kandleid valmistada. Eriti Eestis on sellised õpistud vedu võtnud. Helle Suurlaht luges oma 2004. aasta kursusetöös (toonase Viljandi Kultuuriakadeemia juures) kokku, et tolleks aastaks oli käsitsi tehtud (mitte vabrikus toodetud) 430 Eesti väikekannelt, ja viimastel aastatel on neid veel palju juurde tehtud.

Kuigi väliseesti kandlemeistrid-uurijad on tihti käinud Eestis inimesi ergutamas muuseumieksemplaride jäljendeid tegema, ei saa öelda, et ilma nende panuseta oleks väikekandle tagasitulek kodumaal ära jäänud. Huvi väikekandle vastu oli tõusmas Eestis niikuinii. Eriti tähtsat rolli selles on mänginud kandleõpetaja Tuule Kann (snd 1964), kes tutvus vana kanklèse traditsiooniga, kui ta õppis konservatooriumis Leedus, ja tuli Leedust tagasi 9- ja 12-keelelise pilliga. Tema tarvis tegi Eesti Rahva Muuseumi restauraator Roland Suits ühe vana kandle jäljendi 1990. aastate alguses.

Samal aastakümnendil läks väikekandletootmine lahti Tallinna Klaverivabrikus. Vabrikus oli eestvedajaks Sirje Voitka, kes oli osalenud Kaustise rahvamuusikafestivalil Soomes ja tutvunud viie-keelelise kantelega, mida toodeti vabrikus koolilastele. Sobiva pillimudeli leidmisel aitasid kaasa ka helilooja ja regilaulu ekspert Veljo Tormis, kandleuurija Igor Tõnurist, kromaatilise kandle õpetaja ja Kukulinnu ansambli juht Els Roode, tema õpilane Tuule Kann ja kandlemeister-uurija Andres Peekna USAs.

Tallinna Klaverivabrik tootis 1500-1700 väikekannelt aastail 1990-1997 (Suurlaht 2004). Need Kaarma kuue-keelelise kandle jäljendid sobisid kooli- 
lastele kandlemängu õpetamiseks, aga polnud just kõige parema kõlaga. Kui Keila kandleõpetaja Pille Karras sai võrrelda oma vabrikupilli nendega, mida Peekna ja autor olid teinud Ameerikas, ütles ta: "Minu oma tiniseb nagu sääsk!" Vabrikutootega oli mitu probleemi: kõlakast oli väga väike (nii et hääl polnud kuigi vali), lauad kõlakasti sisekülgedel olid üsna karedad (mis summutab heli) ja keerpulgad olid väga peenikesed (raskendab täpset hääldepanemist ja tekitab katkemise ohtu). Kuna kandleõpetajaid vaimustas käsitsi tehtud kannelde kõla ja klaverivabrik lõpetas kandletootmise, tekkis Eestis turg, kus uued kandlemeistrid leidsid ostjaid oma käsitsi tehtud väikekannelde müümiseks. Kindlasti aitas sellele üleminekule kaasa ka Viljandi pärimusmuusika festival, kus kogenud kanneldajad esinesid erinevate meistrite pillidel, ja meistrid said pakkuda oma varasid pillilaadal. Meistrid oskavad turustada oma kandleid ka arvutivõrgu kaudu.

\section{Vana katmistehnika}

Kui väikekandled hakkasid uuesti levima, kuidas õppisid mängijad nendel mängima? Peekna õppis välislätlaste abiga. New Yorgi kokleansambli juht Andrejs Jansons oli välja andnud õppematerjali 13-keelelisele koklele, ja selles esitatud mänguvõtted põhinesid traditsioonilistel sõrmeasetustel (Jansons 1965). Juba 1960. aastal hakkas Leonids Linauts, kes oli Lätis tegutsenud kunsti- ja muusikaõpetajana, tegema väikekoklesid Ameerikas (Mohntonis, Pennsylvania osariigis) joonistuste ja märkmete järgi, mis ta oli juba enne sõda teinud välitööde jooksul oma kodumaal. Teised välisläti meistrid hakkasid samuti USAs, Kanadas ja Austraalias rohkesti pille tegema, mis võimaldas paljude välisläti kokleansamblite tekkimist, eriti 1960. ja 1970. aastatel. Jansons tahtis oma raamatukesega soodustada uute mängijate ühistegevust, ja Peekna võttis Jansonsi mängusüsteemi omaks. Peekna oli kontaktis ka Milwaukee kandi koklemeistritega (Chicago lähedal), ja nägi oma silmaga, kuidas mängiti koklel vanamoodi.

Jansons soovitas keelte tõmbamist puupulga või tikuga, aga Peekna eelistas mängida paksu ja jäiga nahatükiga. Soome kuulus kantelemängija Martti Pokela oli maininud ühe heliplaadi tagaküljel, et sellisest materjalist tehti vahel plektrone. Peekna kattis teatud akordi jaoks mittesoovitavad keeled vasaku käe sõrmedega ja tõmbas enda poole parema käega, nagu soovitas Jansons, hoides nahatükki pöidla ja nimetissõrme vahel (tiku asemel). Ta tegi ka vahenoppimisi nii parema käe ülejäänud sõrmedega kui ka vasaku käe sõrmedega (mis muidu olid helide summutamiseks keelte peal). Tema mängustiili saab näha televisioonisaates, mis näitab duetti tütrega (ERR 1991). 
Akordide skeem.

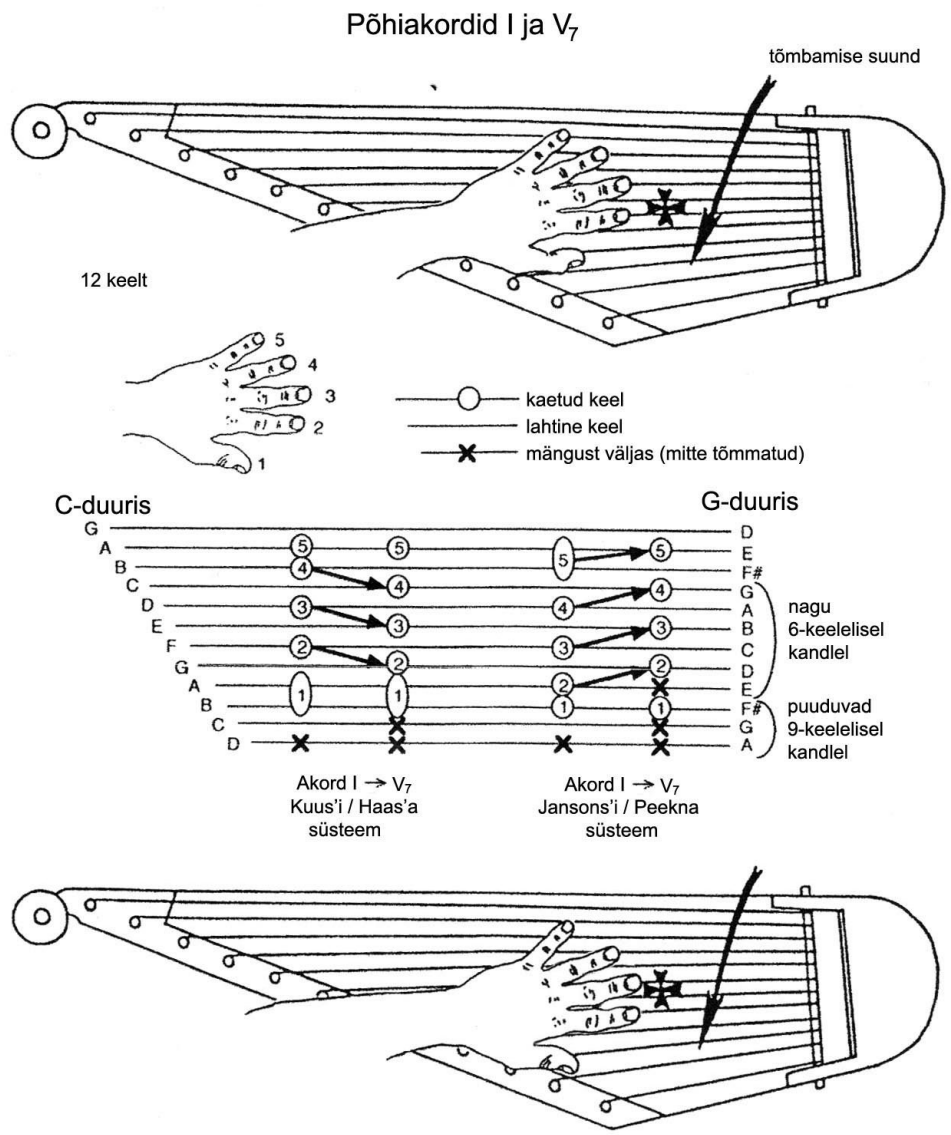

Joonis 1. Katmistehnika väiksel kandlel.

Autor proovis esialgu samamoodi mängida, aga leidis, et see on liiga kohmakas, kui väikesõrm peab I põhiakordi mängimiseks katma kahte keelt korraga (joonis 1). C-duuris I (C) akordi mängimiseks jäävad madal G, C, E, G ja kõrge C katmata, ja väikesõrm (nr 5) vajutab nii alumise A kui ka B (või H) peale. Paljud eesti rahvaviisid kipuvad põhitoonist ehk toonikast (siinjuures madal C) allapoole minema, nii et väikesõrm peab siis samaaegselt katma ja vaheldumisi ka noppima nii A-d kui ka B-d). Autorile tundus mugavam mängida Toronto kanneldaja Alfred Kuusi juhendi järgi (1974), kus väikesõrm katab ainult A-d, ja järgmine sõrm (nr 4) B-d. Keskmine sõrm (nr 3) katab D-d, nimetissõrm (nr 2) F-i, ja pöial (nr 1) siis kõrget A-d ja samaaegselt ka B-d kui on vähemalt 11 keelt). (Jansonsi/Peekna süsteemi järgi oleks nimetissõrm kõrge A peal ja 
pöial kõrge B peal.) Kuus (1922-2008) mängis suurt kannelt, aga lapsepõlves oli ta õppinud mängima esialgu külakandlel ainult üheksat keelt, tõmmates tikuga, isa ja onu õpetuse järgi Pringi külas Valgamaal. Kuus on ainukene teadaolev eesti kanneldaja, kes pani täpselt kirja, kuidas mängiti väikekannelt vanasti katmistehnikaga. Loit käsitleb katmistehnikat küll (1976: 162-164), aga esitab ainult suure kandle mänguvõtteid, kus pikim keel on mängija pool (oli vanasti vastupidi väikse kandle mänguga) ja puuduvad keeled toonikast allapoole.

Kuusi süsteem ühtib enamasti sellega, mis Hannu Saha (1986) esitab oma õpikus kümne-keelelise soome kantele mängimiseks, kus puudub kõrge B (Haas 2009). Üks erinevus on see, et Saha kirjutab keelte noppimisest paljaste sõrmeotstega, aga Kesk-Soomes on mängitud ka tiku ja nahatükiga (Dahlblom 2011: 34). Teine erinevus: Kuusi süsteemis liiguvad sõrmed V7 akordi mängimiseks (siinjuures G7) I akordi asetusest ülespoole (neljas sõrm madala B pealt $\mathrm{C}$ peale, pikk sõrm D pealt E peale) ja nimetissõrm F-i pealt G peale. Saha soovitab V7 mängimiseks liigutada sõrmi allapoole, nagu Jansonski, aga ülespoole V (G) jaoks.

Autor õppis teistsuguse katmistehnikaga mängima ühe teise Toronto kanneldaja eeskujul. Oskar Haamer (1904-1997), kes oli Venemaal sündinud (Novoseljes, Peterburi lähedal) ja Eestis õppinud (Räpinas, Tallinnas, Tartus), sai suure rahvapilliorkestri asutajaks ja juhiks Torontos. Ta mängis tavaliselt päkarauaga oma külakandlel, millel oli umbes 15 keelt (Peekna jutu järgi), aga 1987. aastal esines ta eesti rahvamuusikute kokkutulekul Seedriorus (Cedar Valley, Ontario) Peeknalt laenatud 12-keelelisel Vändra kandlel. Haamer kattis keeli vasaku käe sõrmedega Kuusi moodi, liikuvate sõrmeasetustega (peamiselt I ja V7), aga tikuga tõmbamise asemel noppis ta tookord paar-kolm katmata keelt korraga parema käe sõrmeotstega. Viisi lõpul hakkas ta siblima sõrmeotstega, eriti allapoole, mis oli hoopis teine mängustiil. Etendus salvestati videolindile (Westerblom jt 1987), mis võimaldas korralikult uurida kiire mängu jooksul kasutatud võtteid. Tiit Kao jutu järgi mängis Haamer vahel ka setuvõi venepärase siblimistehnikaga, kus vasaku käe sõrmed olid keelte vahel ja liikusid edasi-tagasi kõlalaua peal akordide kiireks vahetamiseks, nagu gusli mängijad näitavad filmides tehtud 1980-1990. aastate retkedel (Mehnetsov 2009). Haameri mängustiilid ei levinud kuigi laialt, sest ta ei täpsustanud kirjalikult oma mängutehnikaid ega katsunud teistele neid õpetada. Ta isegi häbenes oma vanamoelist mängustiili ja Kao jutu järgi palus selle kasutamise pärast vabandust. Nii et Kuusilt õpitud katmistehnika sai väliseesti väikekandle harrastajate seas peamiseks variandiks, eriti Toronto kandis tänu Tiit Kao korraldatud kandleringile.

Eestis säilis ka vana mängutehnika, aga väikekandle tagasituleku eestvedajad ei teadnud sellest 1990. aastatel õppematerjali otsimise ajal midagi. Kui 
klaverivabrik hakkas 1990. aastal tootma väikekandleid, andis Eesti Rahva Muuseum välja juhendi, mille oli koostanud toona ERMi töötaja ja muusik Jaan Sööt (1990). Juhend põhines soome viie-keelelise kantele mängimiseks mõeldud käsiraamatul (Laitinen \& Saha 1988). Soome raamatukeses esitatakse kolme traditsioonilist mängustiili, kus mõlema käe sõrmed nopivad. Iga sõrm läheb sama keele peale tagasi, kui keel on nopitud. Minoorse akordi mängimiseks soovitatakse ühe keele ümberhäälestamist. Seda on tõesti vaja viie-keelelise pilli puhul, sest C-duuris oleks häälestus mažooris $\mathrm{C}, \mathrm{D}, \mathrm{E}, \mathrm{F}, \mathrm{G}$ ja minooris C, D, Eb, F, G. Aga kuue-keelelisel kandlel (nootidega C, D, E, F, G, A) on mažoorne akord C, E, G ja minoorne akord D, F, A mõlemad kergesti saadaval. Hiljuti ilmunud juhendid (Karras 2010; Reier 2014) põhinevad samuti soome väikekandle juhendil. Pole kindel, kas Eestis kasutati vanasti soomepäraseid mänguvõtteid. Pille Karras teatab oma magistritöös (2011), et Kuus kirjeldas katmistehnikat, aga selle mängustiili üksikasjad jäävad mainimata, sest Karrase töö peateemaks oli mäng moodsatel kanneldel.

Väisaneni vaharullisalvestuste kaudu on teada, kuidas kõlas setu kanneldajate mäng 1913. aastal, aga kahjuks ei saa helide järgi aru, missugused olid sõrmeasetused. Tundub, et tikuga ei mängitud, sest muidu oleks heli teravam, aga nahatükiga tõmbamine kõlab umbes nii nagu sõrmeotstegagi. Vanades kandleteemalistes rahvalauludes mainitakse tihti pöidla ja sõrmedega keeltepeksmist (Eisen jt 1926: 1-14), nii et võib oletada, et löödi allapoole mitme sõrme küünega ja ülespoole pöidla küünega. See on sobiv mängustiil rütmilise tantsusaateks ja kirikukellade imiteerimiseks, mis olid iseloomulikud setu kandlemängu traditsioonile, nagu selgitab Valk (2005: 32). Läänemaalt Kirblast pärit Jaan Ranna kandlemäng (salvestatud 1937. aastal Riigi Ringhäälingus) kõlab nagu mängiks ta tikuga 11-keelelisel pillil, aga pole kindel, millega Rand tõmbas keeli ja missugused olid sõrmeasetused. (Leanne Barbo on lahkelt jaganud vanu helisalvestusi autoriga.)

Alles hiljuti selgus, et vana katmistehnika (nagu Kuus ja Haamer esitasid seda Torontos) säilis Eestis üksikute suurte kannelde mängijate seas. Autor on kaua otsinud selle tehnika esindajaid Eestis (umbes veerandsajandi jooksul) kuid alles 2012. aastal nägi sellist keeltepeksjat. Antsla kanneldaja Ilmar Hellamaa mängib tavaliselt suurel kandlel moodsa tehnikaga (kus vasak käsi mängib saadet ja parem käsi eraldi meloodiat) aga mõne laulu saateks mängib ta akorde vanamoelise katmistehnikaga, kasutades ainult kümmekond keelt oma külakandlel. Ta tõmbab keeli parema käe nimetissõrmega (mitte tikuga), aga katab keeli vasaku käe sõrmedega, just nagu tegid seda Kuus ja Haamer. Hellamaa õppis seda kunsti vanamoodi külameestelt, eriti Benno Pettailt.

Aastal 2015 kohtus autor Tartu kirikuõpetaja ja endise folkloristi Urmas Orasega, kes mängib vahel külakandlel ja diatoonilisel kandlel oma töökohal (vanadekodus, aga mitte laiema kuulajaskonna ees) selliste sõrmeasetustega, 
nagu Peekna õppis Jansonsilt. Peamine erinevus Orase stiilis on, et väikesõrm katab ainult alumist B-d (mitte A-d) ja ta ei tõmba kunagi madalaid keeli (toonikast allapoole). Autori kümne-keelelise kandlega ei saanud ta hakkama. Ütles, et vajab vähemalt 14 keelt oma tuttavate viiside mängimiseks. Ta kasutab vasaku käe sõrmi väga aktiivselt meloodia mängimiseks, ja need pole ainult keelte katmiseks. Mängukunsti õppis ta lapsepõlves vanaisa mängu jälgides. Orase vanaisa Rudolf Tikk (Alatskivilt) mängis katmistehnikaga traditsioonilisel viisil, nii et lühemad keeled olid mängija pool, aga kui mängis "näppimistehnikaga" (meloodiat noppides parema käega ja saadet vasaku käega), olid pikemad keeled mängija pool, nagu eelistavad mõned suure kandle mängijad.

Filme vaadates on autor näinud ka kahe Saaremaa kanneldaja katmistehnikat. Tuule Kanni tehtud videofilmist on näha, et Arno Sooäär (snd 1934 Kaarma vallas Saaremaal), kes praegu elab Tallinnas, tõmbab keeli rahvakandlel parema käega, kasutades lipitsat, mis sarnaneb jämeda tikuga. Erinevate akordide sõrmeasetused on täpselt samasugused nagu Alfred Kuusi juhendis esitatud, ja lühikesed keeled on mängija pool. Ainukene erinevus on, et Sooäär mängib viisi rohkem kõrgematel keeltel kui Kuus õpetas üheksa-keelelise pilli jaoks. Eesti Rahvusringhäälingu arhiivis on TV saade, mis näitab Orissaare kandlemeistri Vassili Sepa katmistehnikat, nii 1988. aastal kui ka palju nooremas eas (vanas filmilõigus). Sepp mängis ka rahvakandlel, lühemad keeled mängija pool. Ta hoidis plektronit parema käega, ja tõmbas peamiselt enda poole. Ta ei kasutanud vasaku käe väikest sõrme üldsegi, sest see jäi keeltest kõrvale, käsitoe peale. Tundub, et tema viisikeeled algasid toonikaga (C-duuris oleks alumine keel C). Viise mängis kõrgematel keeltel ja noppis tihti vasaku käe sõrmedega.

Astrid Böning kirjeldab oma diplomitöös (2002: 8-9 ja Lisa 4-6) Sepa mängutehnikat oktaavis topeltkeeltega kandlel, mille viisikeeled olid (pikimast keelest alates) G, B (H), C, D, E, F, G, A, B (H), C jne. Esimese akordi jaoks katab Sepa sõrm 5 (väikesõrm) alumise viisikeele all asetseva I (C) saatekoori ülemisi keeli (olgugi et need võiksid katmata jääda), sõrm 4 katab B-d (H-i), sõrm 3 kolm katab D-d, sõrm 2 katab F-i ja sõrm 1 (pöial) katab A-d. V akordi jaoks liigub sõrm 4 B pealt üles $C$ peale ja sõrm $3 \mathrm{D}$ pealt $\mathrm{E}$ peale; teised sõrmed jäävad paigale. Need sõrmeasetused klapivad Kuusi süsteemiga, kuid selle erinevusega et Sepa kandlel puudub alumine A. IV ja V akordi mängimiseks liiguvad sõrmed 1-4 just nagu Kuusi süsteemis. Sõrm 5 liigub alumise A puudumise tõttu teistmoodi kui Kuus soovitab, aga põhimõte on sama katmata ja kaetud keelte suhtes. IV (F) akordi jaoks liigub Sepa sõrm 5 üles esimese viisikeele (madala G) peale; V (G) akordi jaoks jääb sõrm 5 saatekoori $C$ keelte peale ja madal G jääb katmata. (Sepa filmitud esinemistes rahvakandlega jäi tema sõrm 5 mängust kõrvale vist sellepärast, et ülemine saatekoor oli küllaltki kaugel madalaimast viisikeelest ja polnudki vaja saatekoori keeli juhusliku löögi eest katta.) 


\section{Päkarauakandle mäng}

Katmistehnika uuem variant on päkarauakandlemäng, mis sai viimasel sajandil väga populaarseks Kagu-Eestis (Tõnurist 2005). Akorde tõmmatakse väikekandle katmistehnikaga, juurde tulevad tugevad bassikeeled (vahel kaetud vasaku käe väikesõrmega) ja kõrged viisikeeled (tõmmatud vasaku käe pöidlal asetseva päkarauaga). Selle puhul on täheldatavad kaks põhilist varianti. Ahunapalu pillimeister Aksel Tähnas (1911-1997), kes õppis teismelisena mängima naabrimeeste järgi, seadis bassikeeled nii, et kõige pikemad keeled moodustasid saatekoori toonika akordi mängimiseks (nt C-duuris C), ja siis on topeltkeeled teiste IV ja V akordide (siin F ja G) jaoks (ERR arhiivist 1989. aasta televisoonisaate järgi). Topeltkeeled viisi mängimiseks algavad toonikaga (siin C, siis D, E, F, G, A, B (H), C jne). Tuule Kanni meiliteatel, 10. märts 2016, võib aga bassikeelte arv ja akordide/funktsioonide järjestus varieeruda Tähnase kannelde vahel. Duuri vahetamiseks olid Tähnasel mõne keele vibreeriva osa lühendamiseks ümberhäälestuse kangid. Tuule Kann ja Pille Karras on avastanud, et Tähnase koduküla kandis on selle stiili peamine esindaja Johannes Arike (snd 1932, elab Järvseljal). Tähnase helisalvestuste ja Arikese näpunäidete järgi on õppinud mängima samasuguse stiiliga Tallinna lõõtspillimängija Juhan Uppin ja teised. Pille Karrase meiliteatel (4. jaanuaril 2016) on selle mängustiili harrastajate pillid häälestatud C- või G-duuris, aga akordide tarvis on neil ühine järjekord alates pikemast küljest: I, IV, V. Ühe või kahe bassikeele asemel võivad olla saatekoorid (keelterühmad), mis meenutavad rahvakandle süsteemi.

Räpina kandist pärit Toivo Luhats (snd 1938) paneb bassikeeled teise järjekorda (pikim G, C, F), ja teised saatekeeled on nagu Kuusi juhendis üheksakeelelisele kandlele (G, A, B, C, D, E, F, G, A). On huvitav, et Jansonsi ja Peekna moodi väikekandlel peab väikesõrm ühe akordi jaoks (IV või F) katma kahte keelt korraga. Toivo Luhats õppis seda stiili oma isalt Elmarilt (1908-1991), ja on õpetanud seda Tallinna noortele ansamblis Piibar juba üle 40 aasta (nende seas on Tarmo Kivisilla, Jaagup Kippar, Andres Abro ja tema poeg Mart). Hiljuti ilmus raamatukene (Luhats 2007), kus ta kirjeldab oma mängustiili.

Jääb selline mulje, et Eestis hakkasid katmistehnikaharrastajad mängima meloodiat suurte kannelde kõrgematel keeltel, mis on huvitavam seade, kui on rohkem keeli mängus. Väikse kandle puhul selline mäng ei kõlba, sest kõrgemate keelte puudumisel tuleb viisi mängida madalate keeltega. Toronto kanneldajad Alfred Kuus ja Oskar Haamer kasutasid vasaku käe sõrmi rohkem viisi mängimiseks, aga päkarauaga saab seda kõrgematel keeltel teha vasaku käe pöial või lipitsaga parem käsi. Pole kindel, kas päkarauamäng on arenenud Sooääre, Orase ja Sepa tüüpi stiilist või vastupidi. On võimalik, et 
inimesed harjusid päkarauaga mängitud viisidega, ja katmistehnikamängijad hakkasid seetõttu eelistama viisi mängimist kõrgematel keeltel (nagu päkarauaga mängitakse viise vasaku käe pöidlaga). Teisest küljest on võimalik, et katmistehnikamängijad tahtsid suurel kandlel proovida mänguviisi, mis kasutas rohkem keeli, ja lõpuks leidis keegi, et päkarauaga on kergem, sest paremal käel pole enam vaja hüpata nii kaugele edasi-tagasi madalate akordide siblimise ja kõrgete viisikeelte tõmbamise vahel.

\section{Viisikandle mäng}

Katmistehnika ja päkarauakandlemängu kõrval on veel üks vanem mängustiil, mis oli juba peaaegu kadunud, aga on viimasel ajal jälle laiemalt levimas. Kui rahvakannel sai Eestis peamiseks kandletüübiks oma kolme keelterühmaga akordide mängimiseks, taandus keerulisem saatemängustiil. Ameerika idarannikul ei löönud klaverivabrikus toodetud rahvakannel eriti läbi, selle kandi välis-eestlaste seas jäi püsima diatooniline viisikannel. Teise maailmasõja põgenikel polnud sugugi kerge kandleid kaasa võtta. Tähtsaks erandiks on suur 34-keeleline kannel, mille Viru-Jaagupi kauplusepidaja ja rahvaansamblijuht Valter Raudkivi (ennemalt Stein, 1902-1980) oli 1935. aastal ise teinud ja viinud Baltimore’i (Washingtoni lähedal). Kandletegemist õppis ta kohalikult meistrilt perekonnanimega Tiismus, kes oli töötanud Peterburi klaverivabrikus, laenas tööriistu ja andis nõu (Raudkivi 1973a ja b). Raudkivi tütar Lilian (snd 1930, abielunimega Esop) õppis ka mängima ja esines isaga, aga nad ei saanud duette mängida enne, kui isa tegi 1967. aastal juurde kolm suurt kannelt, 37 keelega. Kui Liliani minia Anu Esop (1955-1994, neiuna Peets) näitas üles huvi sellise pilli vastu, hakkas nooriku isa Gottlieb Peets (1916-2003) tegema rohkesti jäljendeid tellijatele, tavaliselt 37 keelega. Ta tegi ka jäljendeid ühest vanemast 25keelelisest nn Kandle-Jussi tüüpi kandlest (pika S-kujulise küljega), mis oli 1938. aastal toodud New Yorki. (See läks kahjuks kaduma, kui pillimeister saatis ta omanikule pärast jäljendi tegemist tagasi.) Peets oli elukutselt puusepp, ja tegi mitukümmend suurt kannelt. Ostjad olid peamiselt eesti päritoluga, aga ameeriklane Edward Hopf ja lätlane Gita Veskimets olid ostjate seas ja esindasid heameelega Eestit rahvusvahelistel festivalidel.

1981. aastal algas kandlepäevade korraldamine, algusel Baltimore'i Eesti Majas (Marylandi osariigis) ja hiljem ka eestlaste laagris Lakewoodis ("Järvemetsal”, New Jersey osariigis), Lilian Esopi ja hiljem Tiina Etsi eestvedamisel. 1990. aastate lõpuni tuli peaaegu igal aastal kokku paarkümmend kanneldajat USA idarannikult ja keskelt, ning Kanada idaosast (Toronto kandist). Mängiti peamiselt Peetsi tehtud viisikanneldel. Osalejate seas leidus ka läti kokle ja 
leedu kanklèse mängijaid-meistreid. Kujunes välja kindel rituaal: pillide häälestamine, kandle mütoloogilise algupära meenutamine (Vanemuise muistendi ettelugemine), kanneldajate ring (kus iga mängija esitas soolopala ja rääkis oma hiljutisest tegevusest), isiklik õpetamine, koosharjutamine ja kontsert kohalikule kuulajaskonnale (Rahkonen 1994).

Raudkivi ja Esopi mängustiilis nopivad viisikeeli parema käe sõrmed (peamiselt pöial, nimetissõrm ja keskmine sõrm). Vasaku käe sõrmed nopivad saatekeeli, mis on häälestatud nõndaviisi: madal C, F, G, C, F, G, A, B, C, D. Põhiakordi I mängimiseks 4/4 taktis tõmbavad esimesel löögil neljas (nimeta) sõrm ja keskmine sõrm samaaegselt oma C-keeled (1. ja 4. bassikeele), siis teisel löögil tõmbab pöial kõrge C-keele, kolmandal löögil tõmbab nimetissõrm keskmise G-keele, ja neljas löök on nagu teine löök (kõrge C pöidlaga) (joonis 2). V7 akordi jaoks liiguvad sõrmed ülespoole: nimeta sõrm ja keskmine sõrm tõmbavad alumised G-keeled, siis tõmbab pöial kõrge D-keele, seejärel nimetissõrm B-keele ja lõpuks pöial jälle kõrge D-keele. Neljas akord algab alumiste F-keeltega (nimeta sõrm ja keskmine sõrm), siis kõrge C (pöial), A (nimetissõrm) ja lõpuks jälle kõrge C (pöial). Erinevalt rahvakandlest saab mängida ka minooris. Kui bassikeeltele tuleb juurde kõrge E, siis on VIm (Am) saadaval: esimese löögiga keskmine $\mathrm{C}$ ja A, teise löögiga kõrge $\mathrm{E}$, kolmanda löögiga kõrge $\mathrm{C}$ jne. Kahjuks ei saa IIm (Dm) saatekeeltel mängida, aga viisikeeltel küll, nagu autor on leidnud: esimese löögiga võib keskmine sõrm tõmmata $\mathrm{D}$ keele, siis pöial tõmbab kõrgema A, seejärel nimetissõrm keskmise $\mathrm{F}$ keele jne.

Raudkivi saatemängustiil oli tema oma leiutis (1973c: 3-4). Ta otsustas, et oli kohmakas mängida saadet naabripoisi stiilis, kus pikad keeled on mängija pool ja saatemänguks kasutatav vasak käsi ripub õhus ilma toeta. Raudkivi oli juba harjunud katmistehnikaga, kus lühikesed keeled on mängija pool. Nuputas välja, et kümme keelt on vaja kolme akordi mängimiseks noppimistehnikaga. Eestis oli tütar Lilian ainukene, kes õppis korralikult mängima samamoodi, aga Ameerika idarannikul on nüüd mitukümmend kanneldajat selle stiiliga harjunud.

Samasugune saatemäng olevat tuntud ka Soomes, Perho jõe ääres Kokkola kandis, nagu teatas meilitsi Carl Rahkonen (14. juulil 2015). Ka Eestis on autor näinud midagi samalaadset. Viljandimaalt Karksi-Nuiast pärit Heino Sõna ja tema õpilane Viljandis Eva Väljaots mängivad enamvähem samamoodi. Erinev on vaid see, et pöial ja nimetissõrm ei tõmba oma keeli eraldi ja kordamööda teisel ja kolmandal löögil, vaid korraga mõlemal löögil. 4/4 rütmis mängitakse nagu 2/4. Keeled on natuke teistmoodi häälestatud ka, sest pikim bassikeel on subdominant (C-duuris F), järgmine on dominant ( $G$ ), ja siis on toonika (C), võrreldes C, F, G-ga Esopi süsteemis. Esimesest akordist liiguvad Sõna sõrmed allapoole V (G) ja IV (F) mängimiseks, mitte üles nagu Raudkivi ja Esopi män- 


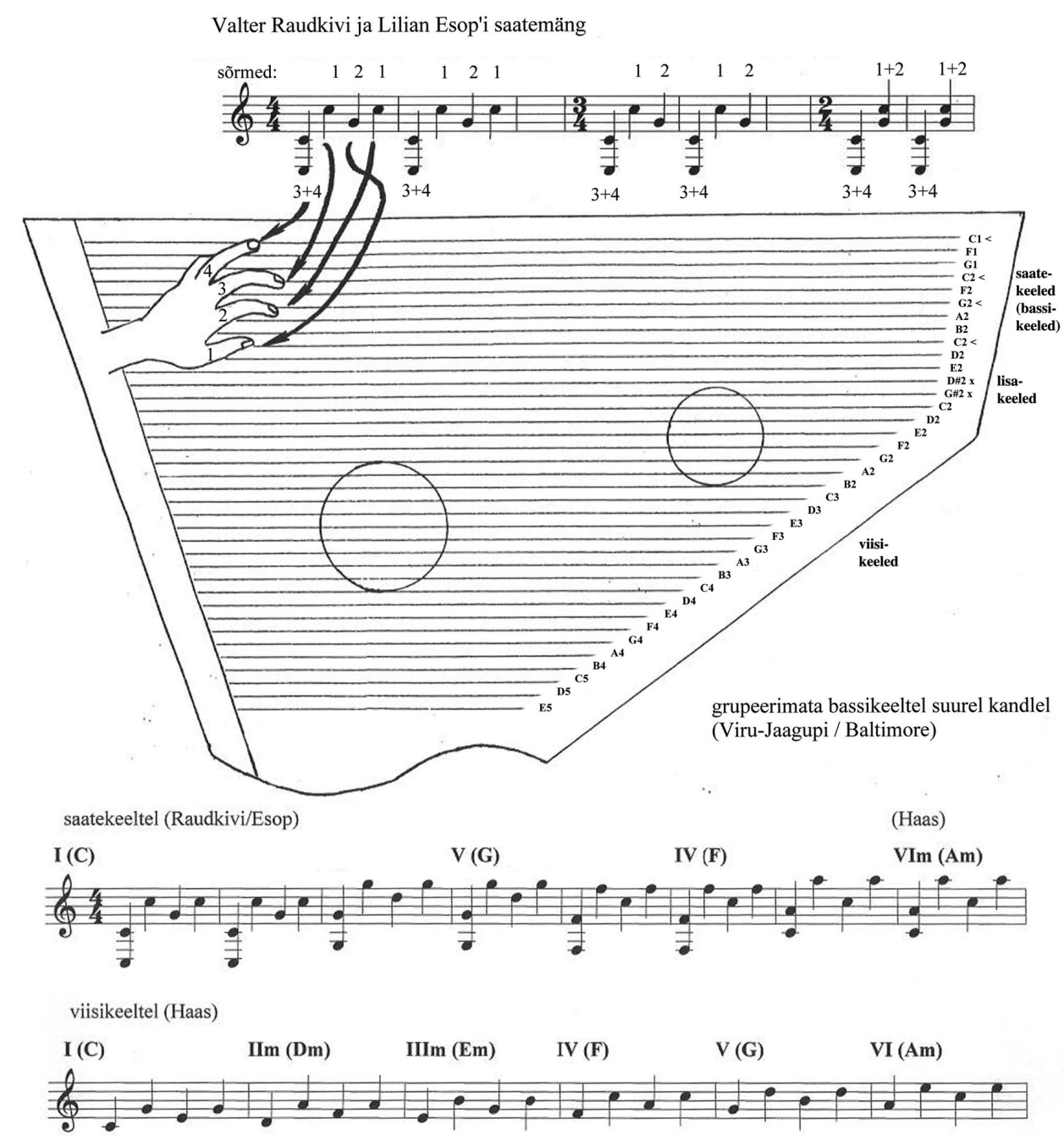

Joonis 2. Saatemäng suurel viisikandlel.

gus. Viisikandle saatemängu stiilid olid Eestis muutunud nii haruldaseks, et teiste suurte kandletüüpide asjaliku kirjeldamise kõrval ei öelnud Loit (1976) viisikandle kohta muud, kui et sellise nimetusega pill tekkis 19. sajandi teisel poolel. 


\section{Kandle kasutamine tänapäeval}

Tänapäeval pole kandlemäng, olgu väikestel või suurtel pillidel, rituaalidega eriti seotud, kuigi vahel mängitakse ikka pulmades, matustel, jaanitule juures, ja eriti väliseesti seltside aktustel. Tantsusaateks külasimmanitel on lõõtspilliga ikka raske võistelda, aga rahvapidudel või festivalidel on kandlel kindel koht olemas. Kandle roll laste muusikaõpetuses on Eestis olulisem kui kunagi varem, ja muusikaõpetajad on kodumaal olnud kõige silmapaistvamad tegelased kandleürituste korraldamisel. On organiseeritud hulgaliselt kandleansambleid, -ringe, -päevi, -õpistuid, -laagreid, -konverentse, -uurimisretki jne. Väliseesti kogukondades pole muusikaõpetaja amet kanneldajate seas kuigi tavaline, aga eestvedajad on koolides ja omapead õppinud ühte-teist muusikateooriast ja -ajaloost ning oskavad tavaliselt noodilehti lugeda. Noodilehed on tähtsamad välismaal, eriti viiside selgeksõppimiseks, sest kandlemängijad saavad seal omasugustega kokku harvemini ega saa ainult kuulmise järgi hakkama.

Mängijaid ja kokkutulemisi on vähem välismaal, kus vahemaad suuremad (näiteks sõitis autor tavaliselt 4-5 tundi Chicago kanti, et seal ansamblis mängida, idaranniku kandlepäevadel osalemiseks tuli sõita kümme tundi). Sellepärast on väliseesti kanneldajad mänginud pigem rahvusvahelistes ansamblites ja festivalidel, aga samas ei saa väita, nagu oleksid kodumaa kanneldajad naabermaade kandletraditsioonidest väga isoleeritud. Väikekandle mängimises kasutatakse tikke või plektroneid tihedamini välismaal, sest paljaste sõrmeotstega on raskem mängida, kui kanneldajad peavad samal päeval pikalt harjutama ja kontserdil esinema. Keelte pinge on tavaliselt suurem väliseestlaste väikekanneldel, sest väiksemates kandlerühmades on vaja valjemaid pille. Kandlemängule lauldakse välismaal vähem kaasa, sest mängijad ja kuulajad on tihti mitte-eesti päritoluga, paljudel on eesti keele oskus ja eestikeelne muusikaõpetus puudulik, täienduskoolidele ja noortelaagritele vaatamata. Välismaal esinevad mängijad tihedamini rahvariietes, sest eneseteadlikult esindavad nad muulaste seas Eestit ja püüavad oma eestlust rõhutada mitmel viisil (mitte ainult pillimänguga).

\section{Torupill}

\section{Torupilli algupära}

Läänemeresoome rahvaste seas olid eestlased ainukesed, kes olid väga vaimustatud torupillist (Tõnurist 1977b: 212). Selle muusikariista teised nimetused eesti keeles on kotipill, lõõtspill, kitsepill ja lihtsalt pill (Tampere 1975: 19; Tõnurist 1976: 47; 2008: 465). Torupill oli Eestis laialt levinud (Rannap 1972: 
28-29), aga traditsioon kestis kõige kauem äärealadel, saartel ja Kuusalu kandis (Tõnurist 2008: 465). Pill oli tuntud ka rannarootslaste seas (Nyberg 1990), kes jõudsid Eestisse keskajal, aga pole kindlaks tehtud, kas nemad tõid pilli kaasa Eestisse või omandasid selle oma uuel kodumaal. Esimene dokumentaalne viide torupillimängu kohta Eestis pärineb 14. sajandi lõpu linnaelanike seast (Nyberg 1990: 242). Hansa Liidu kaupmehed tõid ehk pilli Eesti linnadesse, aga mingisugune primitiivne variant võis levida maarahva seas enne seda, kui arvestada burdoontoruta põiest tehtud vormiga vadjalaste ja poolakate seas (Tõnurist 1977b: 213). Igatahes oli torupill selgesti juurdunud talupoegade seas 16. sajandi keskel (Tampere 1975: 22; Tõnurist 1976: 47).

Torupill on Euroopasse tulnud arvatavasti Lähis-Idast rooma sõdurite või vikerlastest seiklejate kaudu (Allmo 1990: 45). Maailma torupillitüüpide uurija Anthony Baines väidab, et eesti torupill kuulub oma kuju poolest samasse rühma läti ja rootsi omadega (Baines 1960: 69-71, 90-92, 103). Neil kõigil on üksik lesthuulik (mitte kaksiklesthuulik nagu oboel), silindrilised torud ja silindriline bassitoru kõlakamber. Nyberg (1990) näeb ka palju ühist eesti, rannarootslaste ja rootsi pillides. Ingrid Rüütel (2012) leiab, et torupillil mängitud vanades tantsuviisides ja nende lõppriimilistes laulutekstides esineb rootsipärasusi, aga Tampere (1999: 11) teatab veelgi vanemast rahvaviiside liigist, mis polnud tantsudega seotud, hõlmas torupillilugusid ja tekkis enne rootsipäraste tantsuviiside levikut Eestis.

Liitsõna torupill mõlemad osad võivad olla läänemeresoome päritoluga (Metsmägi jt 2012: 542, 370), aga siis jääb mõistatuseks, miks eesti nimetus pole eriti sarnane hõimlaste terminitega, nt liivi ilgõma'g 'hülgemagu' (Viitso \& Ernštreits 2013: 72) ja soome säkkipilli 'kotipill' (säkk on ilmselt laensõna rootsi keelest) ja rakkopilli 'põispill'. (Eestis on põispill hoopis poogenpill.) Karjalaste, vepslaste, isurite, ja saamide seast pole teateid torupillist vana rahvapillina. Eestis oli torupill keskne element rahvamuusikapärandis, tähtsate funktsioonidega, mitmeti arenenud kujundilisusega ja see mõjutas teiste pillide repertuaari ja mängustiile, nt burdoonmäng viiulitel ja lõõtspillidel (Tõnurist 1976: 52; Nyberg 1986: 81-82; 1990: 281). On raske uskuda, et pill on laenatud mõne hõimurahva käest, kus sellel on võrdlemisi marginaalne seisund ja teistsugune nimetus. Pigem on vastupidi: hõimlased laenasid torupilli eestlastelt. Soomes oli pill haruldane, aga on teada, et see oli kasutuses Lampi kandis 18. sajandil. Selle mõisa omanikud ja talupojad olid eelmisel sajandil tulnud Saaremaalt, kus torupillitraditsioon oli juba hästi juurdunud (Leisiö \& Tainio 1988: 9; Allmo 1990: 288). Leisiö etümoloogiline analüüs (2014) viibki järeldusele, et sõna 'pill(i)' on eesti keelest soome keelde jõudnud umbes 1300. aastal. See on ehk pärit alamsaksa- või taanikeelsest sõnast spille 'puuvars, kedervars, silinder', mis oli balti sakslaste seas ka roopilli nimetus ja sobib hästi ka torupilli sõrmilise kohta. (Vt ka Leisiö \& Tainio 1988: 4 ja Allmo 1990: 286-287.) 
On tõenäoline, et torupillimäng jõudis Eestisse mõne indoeuroopa rahva kaudu, nagu ka põllumajandus, loomakasvatus, metallitöötlus ja palju muid kunste. 'Toru' on sarnane läti sõnaga taure 'sarv', mis on omakorda suguluses ürgveise nimetusega (läti taurs, eesti tarvas). Pulli samalaadne nimetus on olemas ka rootsi keeles (tjur), ladina keeles (taurus) jne. Lätlaste ja teiste lõunanaabrite seas olid pillitorude alumised osad vahel tehtud sarvest, aga Eestis polnud selliseid toruotsi, ja toru võib tähendada hoopis 'silinder'. Faehlmann arvas, et nimetus võis tulla pilli häälest, mis on nagu torin, ja jagas Arndti arvamust, et võis olla seos äikese jumalaga Tooru või Taara (nagu skandinaavlaste Thor) (Faehlmann 1848: 684; Arndt 1747: 166). 'Pill' tuleb vist sõnast, mis tähendab 'mäng' läti (spēle), rootsi (spel) või saksa (Spiel) keeles, ja s-täht kadus, sest eesti keeles on kahe kaashääliku liitmine sõna alguses võõras. Huvitaval kombel ei sarnane eesti sõna torupill eriti naaberrahvaste terminitega, nt läti dūdas või dūkas 'sumin' (Priedīte 1988), leedu dūdmaišis või $d \bar{u} d a$, rannarootsi drommpip 'torisev toru', rootsi säckpipa 'kott-toru', saksa Sackpfeife 'kott-toru' või Dudelsack 'korduva tuututamise kott', vene volõnka. Viimane on ilmselt Volõõnia järgi, mis on vene-valgevene-poola-ukraina piiriala nimetus (Baines 1960: 79-80; Tampere 1975: 19), aga venelased ise seda pilli ei mänginud, eriti Eesti lähedal (Tõnurist 1976: 48), kuigi mitmed teised rahvad Vene impeeriumi või Nõukogude Liidu aladel seda tegid (Allmo 1990: 294-295). Muusikariista ehituse kirjeldamise poolest sarnaneb eesti sõna kõige rohkem rootsi ja saksa nimetustega.

\section{Torupilli ehitus}

Autor on uurinud Eestist kogutud torupille Tartus (Eesti Rahva Muuseumis), Tallinnas (Eesti Teatri-ja Muusikamuuseumis; Ajaloomuuseumis), Paides (Järvamaa Muuseumis), Pärnus ja Viljandis (linnamuuseumides), ning Stockholmis (Lavakunstimuuseumis). Üksikutes saarte ja Soome muuseumides on uuringud veel tegemata, kuid sealseid pille on nähtud fotodel. Viljandimaa Riidaja Torupillitalu meistrite viimasel ajal tehtud pille on samuti uuritud.

Torupill annab suhteliselt ühtlase hääle koti tõttu, mis oli tehtud pargitud loomakehaosast, kõige sagedamini hülgemaost; harvemini lehma, põdra või hane maost; sea või lehma põiest; või siis koera, kitse, lehma, kassi või teise looma nahast (Rannap 1972: 30). Mängija puhub õhu kotti puhumistoru (putk, napp) kaudu, mille ülemine ots on tavaliselt ovaalne ja natuke ära lõigatud, nii et seda on kergem hammastega paigal hoida. Alumine ots on ümmargune ja selle küljes (koti sees) võib olla klapp või ventiil, mis takistab koti tühjenemist sama toru kaudu. (On ohtlik, kui mängijab hingab oma kopsudesse kotis kasvanud baktereid ja seeni.) Maost tehtud kotil on söögitorust ja soolikast pikendused, 
ja viimane lõpeb 1-3 bassitoruga (joonis 3, vt lk 114). Muust materjalist tehtud kott on tihti samuti mao kujuga ja selliste pikendustega.

Sõrmilisel oli vanasti tavaliselt seitse sõrmeauku, kaasa arvatud on üks kõrge (vasaku käe jaoks) pöidlaauk tagaküljel. Aukude ääred on tihti ära lõigatud, nii et sõrmeotstel oleks mugavam vajutada. Vanadel pillidel on alumised augud suuremad kui ülemised, võib-olla selleks et madalad toonid oleksid kuuldavamad. Kui mõne augu toon on natuke häälest ära, võib ühele servale panna mesilasvaha, nii et hääl läheb natuke kõrgemaks või madalamaks. Vanasti oli sõrmilise alumisel otsal kaks väikest viltust küljeauku, millesse pandi oksakesi või õlekõrsi hääle kontrollimiseks (Tõnurist 1976: 49). Selliseid asju pandi vahel ka toru alumisse otsa, et hääl oleks puhtam (Söderbäck 1940: 210).

Hääl tuleb piugust ehk kotist välja surutud õhu tõttu vibreerima pandud keelest (tavaliselt sisselõikega pilliroojupist või lamedast ava peale seotud rootükist, mis sarnaneb klarneti keelega; harvemini hanesuleotsast). Bassitoru (burdoon, käi) koosneb tavaliselt kahest osast, mille ühinemiskohal saab pikendamise või lühendamisega häält muuta. Bassitoru alumises otsas on silindri- või munakujuline kõlakamber, mis võimendab pidevalt toonika või dominandi tooni. Kotis on pakud, milledesse pannakse torude otsad. Rippuva bassitoru ümber võib olla vööst või nöörist silmus, mis on ka ühe käe ümber ja hoiab pikka toru horisontaalasendis, nii et see ei takista käimist ega istumist ja hääl ei sumbu vastu maad ära. Torud ja pakud on tavaliselt treitud ja kaunistatud kriipsude või vagudega, vanematel muuseumieksemplaridel vahel ka nikerdatud. Puuosad on tavaliselt lakitud ja tihti peitsitud pruuniks. Maost kott on tavaliselt samuti peitsitud.

\section{Torupilli mängutehnika}

Mängimiseks surutakse kotti tavaliselt kätega vastu rinda, nagu on näha vanadelt joonistustelt ja fotodelt, mis pärinevad 17. sajandi keskpaigast 20 . sajandi alguseni (Pulst 1973; Tampere 1975; Nyberg 1990), aga kott võib olla ka kaenla all. Mängitakse nii seistes kui ka istudes. Vanade fotode järgi tundub, et mängiti nii nn kinnise kui ka lahtise sõrmitsemise stiiliga. Kinnises süsteemis kaetakse enamik aukudest pidevalt ja tõstetakse üksikuid sõrmi, nagu vaja soovitud toonide jaoks. See tekitab särtsuvat ja vulisevat heli. Lahtises süsteemis tõstetakse sõrmi kordamööda, nii et alumised augud ei ole kaetud kui mõni ülemine auk on katmata. See annab puhtama hääle, kus toonid eristuvad selgemini. Helide kaunistamiseks mängitakse tihti eellöökide, trillerdamiste ja vahepiuksudega. Helitugevust ei saa eriti muuta. Pill on valjem kui pigistatakse kotti kõvemini, aga siis võib toon minna liiga kõrgeks ja piuk lõpuks kinni (vaikseks) jääda. 
Helirea suhtes on eesti torupill tavaliselt diatooniline, nii et pooltoone ei saa mängida. Tüüpiline helirida koosneb skaala kuuest esimesest noodist, pluss põhitooni all seitsmendast noodist. Rõhuv enamik vanadest (enne sõda) kirjapandud või sissemängitud torupillilugudest jäävad sellise helirea ulatusse. Kui on piisavalt palju auke, võib juurde tulla alumine dominant, samuti kõrge 7. ja oktaavnoot.

Viimasel ajal on kõige agaramad pillimeistrid Riidajast pärit Ants Taul ja tema poeg Andrus tavaliselt teinud pille G-duuris. Kõige traditsioonilisem sõrmiline on sellise helireaga: madal D (puudub alumine E) F\#, G, A, B, C, D, E. Lisaaukudega on ka teisi noote saadaval.

\section{Torupilli kasutamine}

Vanasti uskusid eestlased, et elavast liigist tehtud pilliosas kestis elujõud edasi. See oli kooskõlas esivanemate animalistliku usundiga. Saarlased arvasid, et mingisugune jumal (metsavaim?) oli torupilli burdoonis, sest bassitoru oli tehtud metsas kasvanud puust (Arndt 1747). Samuti arvati, et koera kaeblik vingumine selle poomise ajal, kui taheti nahast teha õhukott, ennustas pilli tämbrit (Tõnurist 1976: 48-49). Leidub isegi teade uskumusest, et pilli jõud võib takistada surma, seepärast murti Kolga-Jaani viimase mängija torupill tema matustel rinna kohal puruks (Rannap 1972: 30).

Torupillil oli vanasti tähtis osa usuga seotud pidudes. Balthasar Russow kirjutas 1584. aastal, et igas külas oli rohkesti torupille, mida mängiti nii meelelahutuseks kui ka lõkketule juures rituaalides, kus olid segunenud ristiusu ja paganluse elemendid (Russow 1967: 87-88, 228; Leichter 1982: 126-127). Talupojad tõid vahast tehtud taluloomade kujusid kirikualtari juurde, otsides kaitset loomade haigestumise vastu, selle järel pidutsesid juues, lauldes ja tantsides orgialiku korratusega torupilli saatel. Alates aastast 1680 leidub teateid (eriti Lääne-Eestist), et torupillimängijad saatsid Metsiku kultuse rongkäike, kus kanti õlgedest tehtud mehe või naise kuju, lootes, et see tõrjub eemale ohud kohaliku rahva põlluviljadelt, karjadelt ja kaladelt (Västrik 1998; Tampere 1975: 22; Leichter 1982: 129). 19. sajandi alguses käidi hiites ja teistes pühapaikades torupilli saatel tantsimas (Leichter 1982: 136).

Torupillipuhujad ratsutasid hobustel kuulutaja rollis, kui teatasid mässajate "kuninga" saabumisest 1560. aasta talupojaülestõusu ajal (Tõnurist 1976: 49; Leichter 1982: 125; teate allikas oli Johannes Renner 1556-1561) ja juhatasid pulmaronge (Olearius 1996: 121, teade on 1630. aastate kohta; Andersson 1961: 18; Leichter 1982: 127). Torupillipuhujad olid ka arhailiste riituslike sabatantsude eesotsas ning saatsid mardilisi ja jõululauljaid (Tõnurist 1976: 50), samuti ristseid ja Põhjasõja-järgse katku ajal matuseronge (Leichter 1982: 129). 
Torupill oli vanasti tähtis ka ilmalikes tegevustes. Mõisnikud võtsid pillimehi oma teenistusse, et luua pidulikku õhkkonda lõikustöö ajal või ergutada tööpingutust. Mängijad tegid naljakaid hääli aeglaste tööliste taga, mis tõmbas tähelepanu laiskadele ja sundis neid töökamatele järele jõudma (Tampere 1975: 22; Tõnurist 1976: 50; Leichter 1982: 128, 132, 134, 136-137). Talupojad olid harjunud torupillimänguga ka omasuguste poolt korraldatud talgutel. Linnades kutsusid kaupmehed torupillimängijaid esinema, et talupoegadest kaubitsejaid pidude juurde meelitada, aga elukutseliste linnamuusikute huvide kaitsmiseks piirati seaduste-määrustega torupillimängijate esinemisvõimalusi (Leichter 1982: 126, 129, 136). Teisest küljest oli torupill seotud ka ohjeldamatusega, sest seda mängiti kõrtsides ja paganliku maiguga pidudel-rongkäikudel. See seletab, miks sattusid pillimehed kirikuvõimude taunimise ja isegi põlu alla, eriti pärast katoliku usu taandumist 16. sajandil (Leichter 1982: 126-130).

20. sajandi alguseks oli torupill taandunud peamiselt viiuli ja lõõtspilli ees. Kuigi vanad torupillimängijad olid 1920. aastatel ikkagi aktiivsed ja hinnatud ning tegid 1930. aastatel helisalvestusi (Pulst 1973; Kiviberg 1994), kadus nende teenuste järele nõudmine pulmades ja teistel üritustel. Sel põhjusel müüski Pakri saarte "viimane" torupillimängija Adam Söderström 1926. aastal oma pilli Rootsist tulnud uurijale (Söderbäck 1940: 210-214; Rehnberg 1943: 23-24). Nyberg (1990: 250) teatab, et Johannes Engström tegi väikse torupilli umbes 1937. aastal Väike-Pakril, aga kas meister ise sellel mängis või andis kellelegi teisele puhumiseks, pole teada. Vanad torupillilood aga ei kadunud, sest neid mängiti edasi lõõtspillil, ka Rootsis pärast põgenemist (Nyberg 1986: 80-82). Siiski läks suur osa kogenud mängijate teadmistest torupillitraditsioonide kohta kaduma.

\section{Torupilli päästmine}

Viimane mängija, kes oli pärimuslikus kontekstis õppinud seda kunsti, oli hiidlane Aleksander Maaker (Torupilli-Sass, 1890-1968), kes oli kuulsa TorupilliJussi (Juhan) Maakeri (1845-1930) vennapoeg. Õnneks andis Torupilli-Sass osa oma teadmistest edasi Olev Roometile (1901-1987), kes oli elukutseline viiuldaja ja laulja Tallinnas. 1970. aasta laulupeoks korraldas Roomet pillimeistri Voldemar Süda abil 25 muuseumieksemplari jäljendi meisterdamise. Need polnud kuigi kõlblikud kontsertesinemiseks, aga sobisid demonstreerimiseks ja salvestamiseks, ning see innustas teisi torupillimängijaks hakkama. Nende seas oli Ain Sarv, kes mängis Leegajuse ansamblis ja õpetas rahvamuusikat Viljandi Kultuurikolledžis (Kiviberg 1994), mis on nüüd seotud Tartu Ülikooliga.

Teine silmapaistev torupilli tagasitoomise eestvedaja on Ants Taul Riidajast, kes sai Eestis peamiseks torupillimeistriks. Ta õppis mängima vanal sõrmilisel, 
ise nuputas välja, kuidas teha sobiv kott (alguses kummist sisemine kott, mis oli kaetud riide või kunstnahaga, nüüd on kott nahast), piuk ja teised osad. Ta mängis lühidalt Leegajuses, asutas siis ansambli Torupill, tegi helisalvestusi, sai õpetajaks Viljandi kultuuriakadeemias, ja ehitas külalistemaja oma Torupillitalus. Peaaegu kõik tänapäeval mängitavad torupillid Eestis ja väliseestlaste seas on tema tehtud. Meistriks on saanud ka tema poeg Andrus.

Arvestades kundede soovide, praktiliste vajaduste ja omaenda uudishimuga, on Ants Taul proovinud uusi materjale ja tunnuseid. Leiutas näiteks liikuva traadijupiga seadeldise, millega saab kiiresti panna bassitoru häälde ilma piugu väljavõtmiseta kotist; pani augu bassitorusse, mille vastu saab küünarnukiga vajutada või mitte vajutada, et mängida vaheldumisi mažooris või minooris samas loos; pani lisaaugu sõrmilisse, et saaks mängida pooltoone; tegi poolauke sama põhimõttega, mille tõttu saab mängida kromaatilisi lugusid ja teha duurivahetusi mängu jooksul jne. Poeg Andrus on samuti teinud uuendusi, näiteks piugu otsa pandud veekoguja (mis takistab bakterite-seente kasvu koti sees) ja keeratav nupp bassitoru keskel (millega saab burdooni kiiresti ümber

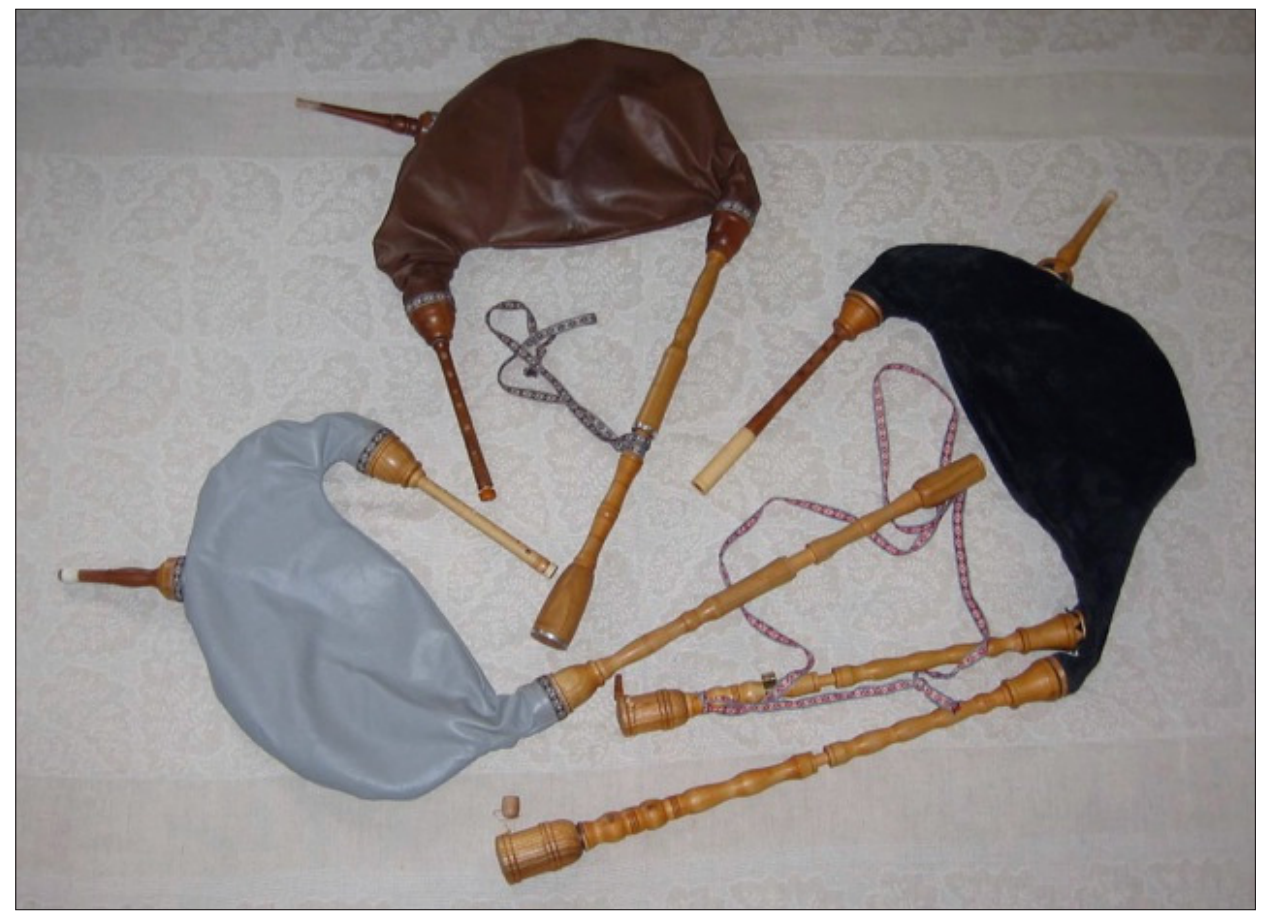

Foto 4. Selliseid torupille tegi Ants Taul (Riidaja). Ain Haasa foto 2007. 


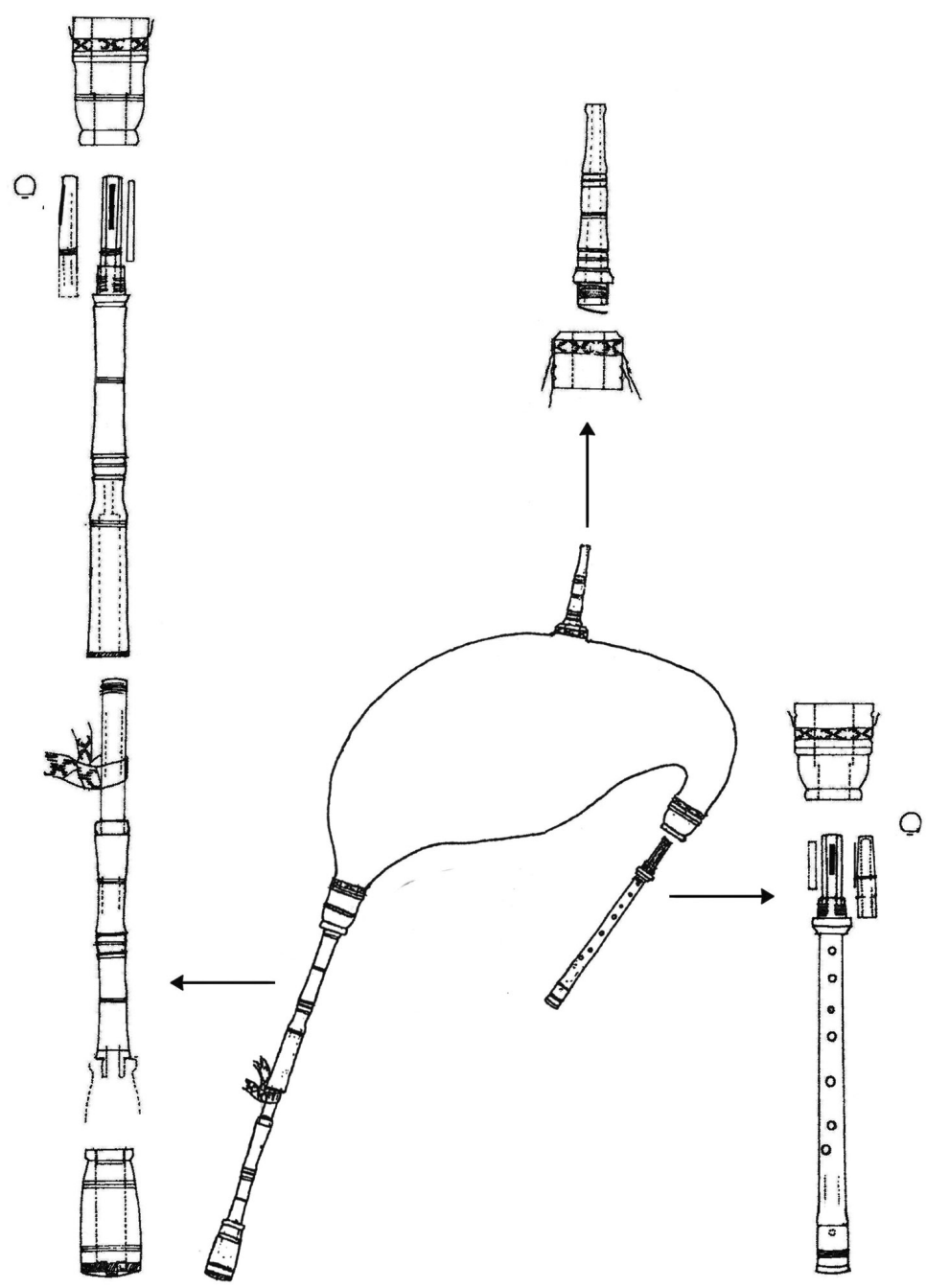

Joonis 3. Ants Tauli tehtud torupilli osad.

häälestada minoorduuris mängimiseks). Nendele uuendustele vaatamata on Taulide pillid üldiselt traditsioonilise kujuga (joonis 3 ja foto 4).

Ants Tauli õpilaste seas on mitu naismängijat (Celia Roose, Sandra Sillamaa, Cätlin (neiuna Jaago) Mägi), kes on silmapaistvad rahvamuusikaõpetajaduurijad. Linnutaja ansamblis (Vändra kandis) on mitu naismängijat. (Vanad fotod näitavad ainult meesmängijaid.) Silmapaistvad järetulijad meessoost on Juhan Suits (praegu torupilliõpetaja Viljandis) ja Ando Kiviberg (Viljandi 
pärimusmuusika festivali korraldaja, endine Eesti Pärimusmuusika Keskuse juht Viljandis, praegune Viljandi linnapea). Tauli mängustiili saab näha YouTube’i videos, kus ta mängib duetti tütre Triinuga (https://www.youtube. com/watch?v=ze-7UPLGIYU).

Väliseestlaste seas on torupill vähe levinud. Põhja-Ameerikas hakkasid Tiit Kao (Toronto kandis), Tiina Ets (Baltimore'is) ja autor (Indianapolises) mängima pärast seda, kui Ants Taul sõitis 1988. aastal Ameerikasse mitme müügis pilliga, näitas sõrmeasetusi ja mängutehnikat videolindi abil ning ostis teenitud rahaga paremaid seadmeid ja materjale pillitegemiseks. Lõuna-Austraalias (Adelaide'is) mängivad Aaron Tamme ja Kustas Tiivas torupilliduette. Tamme on hakanud torupillimeistriks ja selle artikli autor on saanud pilliparandajaks. Nüüd saab ka internetis mitme harrastaja kodulehekülje vahendusel andmeid pilli mängutehnika ja hooldamise kohta. Välismaal leidub estofiile ja hõimlasi, kes on tellinud torupille Eestist. Karjala pealinna Petrozavodski ansamblis Myllärit mängitakse näiteks Eestis tehtud pillil.

\section{Hiiu kannel}

Autor on uurinud Eestis tehtud Hiiu kandleid Tartus (ERMis), Tallinnas (ETMMis ja Ajaloomuuseumis), Haapsalus (Läänemaa Muuseumis), Stockholmis (Lavakunstimuuseumis), Bloomingtonis (Indiana Ülikooli Mathersi Muuseumis, USAs). Stockholmi kandis on ka uuritud Vormsi põgenike Rootsis tehtud pille, mis on praegu nende järglaste omaduses. Soome ja vene muuseumides leidub veel üksikuid eksemplare, mis on pildistatud ja väga täpselt kirjeldatud Niemineni väitekirjas (2008). Mängutehnikat kirjeldatakse põhjalikult Janne Suitsu magistritöös (2010).

\section{Hiiu kandle algupära}

Poognaga mängitud lüüra on muinasaja pill, mis jõudis Eestisse rannarootslaste kaudu. Kõige vanem kujutis sellest pärineb 11. sajandi Iirimaalt. Enne seda oli nopitav lüüra (käeauguga keelpill) laialt levinud Põhja-Euroopas ja ilmselt arenes sellest nii väikekannel kui ka poogenpill, mida me tunneme tänapäeval kui Hiiu kannelt. Poognamäng võis tulla mauride kaudu Hispaaniast, kes olid kontaktis iiri keltidega Loode-Prantsusmaal või viikingite kaudu, kes sõitsid oma laevadega nii Briti saartele kui ka Venemaa jõgede kaudu Bütsantsi. Kas viikingid viisid poogna Iirimaale või võtsid uue riista sealt, jääb ebaselgeks. Igatahes on märkimisväärne, et poognaga mängitud lüüra püsis rahvapillina 
kõige kauem Eestis, Karjalas, Kagu-Soomes, Rootsis ja Walesis - kõik on alad viikingite laevateedel. Esimesed kirjalikud tõendid mõnest rannarootsi asundusest Eestimaal pärinevad 13. sajandi lõpust Haapsalu kandist, varemast ajast on teada rootsipäraseid arheoloogilisi leide Lääne-Eestist (Hoppe 2001-2002; Reinholdson 2002).

Eesti aladel mängiti sellist pilli peamiselt Noarootsi poolsaarel, Vormsil, Hiiumaal ja Saaremaal. Pole teada, et Pakri saarte, Harjumaa ranniku või Ruhnu saare rannarootslastel oleks selline muusikariist olnud. 20. sajandi alguseks oli pill levinud ka eestlaste seas, eriti Noarootsi kandis. Rannarootslaste nimetus oma poogenpilli kohta oli tagelharpa või talharpa, mis tähendab 'jõhv-harf'. Soomlastel-karjalastel olid ka sarnased terminid: jouhikantele ja jouhikko. Hobusejõhvist tehti nii poogenpill kui ka keeled, aga keeled võisid olla ka sooltest või traadist. Ühe Rootsist leitud pilli nimetus oli sotharpa 'tuhaharf'. Eestlaste seas olid levinud nimetused Hiiu kannel, Rootsi kannel ja vibukannel (poogna järgi). Krista Sildoja on soovitanud Hiiurootsi kannel, kuna Vormsi saare teine nimetus on Hiiurootsi. Just Vormsil mängiti seda pilli kõige kauem, ja sealt on korjatud rohkem muuseumieksemplare kui kusagilt mujalt (Nieminen 2006; 2008). Musikoloogide seas on pilli nimetuseks poogenharf või poogenlüüra - rootsi stråkharpa, saksa Streichleier, inglise bowed harp/lyre.

\section{Hiiu kandle mängutehnika}

Mängutehnika suhtes leidub rohkesti andmeid ainult Eesti ja Soome-Karjala traditsioonide kohta, ja need on väga sarnased. Istudes hoitakse pilli põlvede vahel vertikaalselt või reite peal horisontaalasendis. Vasak käsi ulatub tagaküljelt läbi käeaugu ja vajutab sõrmeselgadega või küüntega vastu keeli vabas õhus. Parem käsi lükkab-tõmbab poognat roobi lähedal. Keeled häälestatakse keerpulkadega (virblitega). Kõlalaud on tavaliselt natuke kaares (keelte all kõrgem kui kõlakasti servadel) ja selle all võib olla pulk (nagu viiuli kõlakastis). Kõlaaugud (resonantsavad) on tavaliselt S-kujulised (viiuli moodi) või ristikujulised. Kõlakast on enamasti ristkülikukujuline ja käeauk samuti. 20. sajandi alguses tegid pillimeistrid vahel kõlakastile sisselõiked nagu viiulil.

Keeli oli kaks kuni neli (Eestis tavaliselt neli, Soomes-Karjalas kolm). Meloodiat mängitakse peamiselt esimesel keelel, mängija silmadele kõige lähem), vahel ka teisel keelel (eriti Eestis). Kolmas keel on toonika (vahel madalas oktaavis) ja neljas keel samuti (põhitooni tugevdamiseks). C-duuris oleks selline häälestus (lähimast keelest alates) D, madal G, C (või madal C), madal C. Tõmmatakse kahte-kolme keelt korraga. Kui mängitakse esimesel keelel (kus saab D, E, F, G, A ja kõrgemaidki noote kätte, kui väikesõrmel on ruumi käeaugus nii kaugele ulatuda), siis tõmmatakse burdoonina teist keelt (madalat 
G-d) samaaegselt. Kui on vaja toonika nooti (C-d), siis tõmmatakse kolmandatneljandat keelt, mõnikord ka teist keelt, kui mängija soovib sealt G-tooni juurde lisada. Nimetissõrmega saab D-keelt lühendada nii, et tuleb E noot, keskmine sõrm annab F-i, nimeta sõrm G, väikesõrm A ja kõrgemaid noote. Teisel keelel (lahtiselt madal G) annab nimetissõrm madala A, keskmine sõrm B (H), nimeta sõrm C, väikesõrm D. Kui käeauk on piisavalt lai, nagu eesti pillidel, saab isegi kolmandal ja neljandal keelel madalaid noote vahetada, aga soomekarjala pillidel on käeauk selleks liiga väike. Duuri vahetamine nõuab roobi ümberpaigutamist. Eesti pillidel olid keerpulgad tavaliselt oma raamis, mis oli kinnitatud kõlakastist ulatuvatele aisadele. Soomes-Karjalas oli kõlakastil samast puupakust tehtud labakandle-taoline pikendus, millesse tehti väiksem mänguava kui Eesti pillidel ja puuriti sellesse augud keerpulkade jaoks.

\section{Hiiu kannel noateral}

Soome-rootsi etnomusikoloog Otto Andersson avastas Hiiu(rootsi) kandle, kui ta käis 1903. aasta lõpus Vormsil uurimisretkel. Ta kirjutab oma väitekirjas (1923) ja raamatus (1930), et leidis tollal ainult kaks mängijat, kes said talle näidata omatehtud pille ja mängukunsti: Hans Renkvist (Rönnqvist?, 1849-1906) ja Urbas Anders Ahlström (1873-1959), mõlemad Borrby külas. Nende repertuaarist sai uurija kirja panna 30 viisi. Noarootsi mängijaid polnud enam kusagilt leida. Viis aastat hiljem (1908) nägi Andersson hiidlast Jüri Bruusi, kes oli eestistunud rannarootslane ja mängis Helsingi kai ääres Hiiu kannelt rahateenimiseks. Salvestati tema palasid, mis tulid arhiivist välja alles 2005. aastal (Nieminen 2006: 112). 1920. aastal otsis Andersson uusi andmeid ajalehekuulutuse kaudu (Kustbon, 18. veebruar, nr 7, lk 28), ja sai Vormsi õpetajalt John (Johan) Berggrenilt teada, et Hullo küla mängija Anders Vaksam oli ikka olemas. Berggren saatis ka jutte ja mälestusi Hiiu kandlest. 1930. aastatel sai (Teatri- ja) Muusikamuuseumi asutaja August Pulst tuttavaks kolme mängijaga: Anders Appelblom (Kersleti külas Vormsil) ning eesti soost Aadu Volberg ja Mart Kaasen (mõlemad Taeblas, Noarootsi lähedal) (Suits 2010; Sildoja 2014). Appelblom on ilmselt sama mängija, hüüdnimega Mas-Bill (mis tähendab 'Matsi talu sulane'), kellest Anders Lindström kirjutas (1967), et mees oli põlu all oma paganliku muusikariista ja ilmalike laulude pärast. Juba 1870. aastatel olid Hullo kandi elanikud põletanud ära peaaegu kõik oma ilmalikud pillid, mida oli kasutatud pulmapidudes ja noorte lõbustustel (Andersson 1930: 112).

Teise maailmasõja ajal põgenes enamik rannarootslastest Rootsi. Erandiks oli kooliõpetaja Berggren, kes oli hakanud mängima Hiiu kannelt (nagu seletas tema tütar Lena Weesarele Stockholmis hiljuti), aga ta suri 1941. aasta küü- 
ditamise järel. Pole teada, et keegi põgenikest oleks Eestist oma Hiiu kandle kaasa võtnud. Urbas Anders Ahlström, kellega Andersson kohtus 1903. aastal, mängis Rootsis vist ainult lõõtspilli.

Imekombel jäi Hiiu kandle traditsioon väga kauaks püsima Hiiumaalt 1781. aastal küüditatud rannarootslaste seas, kes sattusid Ukrainasse. Nende Gammalsvenskby külast emigreerus 1913. aastal Kanadasse (Vancouveri kanti) Johannes Simonsson Hoas, keda pildistati 1960. aastatel mängimas enda tehtud pilli, mis oli jäljend tema abikaasa vanaisa Andreas Hindrikssons Sigaleti Hiiu kandlest (Hedman 2002: 5). On märkimisväärne, et Hoasi pill oli väga sarnane sellega, mille Anders Vaksam tegi ja Söderback pildistas 1923. aastal Vormsil (vt samas artiklis). Mõlemal pillil on pikk ja kitsas ristkülikukujuline kuju, ning südame- ja S-kujulised kõlaavad. Pole selge, kas keegi Vancouveris seda traditsiooni jätkas.

\section{Hiiu kandle päästmine}

Stockholmi kandis tõid Hiiu kandle unustusest välja Teise maailmasõja põgenikud. Esimene teade pärineb 1968. aastast, mil vormsilane Anders Westerberg (1912-2000) esines rannarootslaste seltsi juubelil kahe enda tehtud pilliga - Vormsi ja Noarootsi tüüpi (Kustbon 25: 3. sept 1968, lk 3, 5). Kuna muuseumikogudes (täpsemalt Stockholmi Muusikamuuseumis) on säilinud ainult üks Noarootsi pill, on tõenäoline, et Westerberg käis muuseumis vanu Hiiu(rootsi) kandleid vaatamas, ja tegi nende järgi endale uued pillid. Ta oli Vormsi kodukülas (Kersletis) mänginud enda tehtud tšellol poogenpilli-kvartetis, kus Johannes Österberg (1919-1975) mängis enda tehtud viiulit. Österberg oli ka Hiiu kandle meister, mängukunsti õppis ta 14aastaselt (st 1933. või 1934. aastal) Mas-Billilt, kes oli samas talus (Kampesa) sulaseks. Styrbjörn Bergelti teatel (1979: 4) oli Österbergi õpetajaks olnud Mas-Anders, mis klapib autori oletusega, et Mas-Bill oli tegelikult Anders Appelblom (1861-1939). Võib oletada, et samast külast pärit Westerberg ka õppis just tema abil Hiiu kannelt mängima.

Westerberg ja Österberg esinesid tihti koos, aga kui 1975. aastal näidati telesaadet rannarootslaste muusikast, esines noorem mängija Österberg üksinda. See oli ainult mõni kuu enne tema surma, aga õnneks nägi seda programmi rootsi muusik Styrbjörn Bergelt (1939-2006), kes sai võtmeisikuks pillitraditsiooni tagasitoomises Eestisse. Bergelt oli 1971. aastal leidnud oma kadunud isa asjade seast Hiiu kandle, mis oli pärit uurija Otto Anderssonilt (arvatavasti Vormsi tüüpi muuseumieksemplari jäljend), aga ei teadnud mängutehnikast kuigi palju, enne kui ta nägi Österbergi esinemist televisioonis. Bergelt kohtus mõlema Kersletist pärit mängijaga, ka Johan Ahlströmiga (1901-1989), kes 
oli Borrby küla Urbas Andersi poeg, samuti Hiiu kandle mängija ja meister. Nendelt sai ta täpsustusi mängutehnika kohta ja õppis uusi lugusid. Bergelt korraldas pärast Stockholmi kandis Vormsi-pärase pilli tegemise ja mängimise õpistuid, saatis vanatantsu esitajaid, tegi helisalvestusi ja esines raadios Svante Lagmaniga, kes on rannarootsi juurtega ja hakkas Bergelti õpetusel mängima Westerbergi tehtud pilli. Bergelt avaldas Leydoni filmis (2006) pettumust, et rootsi rahvamuusikud ei tunne erilist huvi talharpa vastu. Tahavad pigemini mängida nyckelharpat (nuppviiulit), mis on nagu arenenud talharpa selle poolest, et mängija vajutab klahve või nuppe, ja resonantskeeli on juurde lisatud, aga keeled on ikka vabas õhus ja sõrmlauda pole. Välis-rannarootslaste seas on ainult Sofia Joons (Stockholmis) ja Svante Lagman (Linköpingis) saanud aktiivseteks mängijateks, aga mõlemad esinevad tihti nii rannarootslaste üritustel kui ka laiema publiku ees Stockholmis.

Mängides Hiiu kannelt esinemistel USAs, vahel koos välislätlastega Indianapolise rahvapilliansamblis Siilikesed (Hedgehogs), on autor kogenud, et selline pill ei seisa hääles nii hästi kui kannel või torupill. Teistest väliseesti mängijatest pole kuulnud, võib-olla sellepärast, et nende vanemad ja vanavanemad ei teadnud Hiiu kandlest midagi, sest see oli enne sõda peamiselt rannarootslaste pill. Eesti rahvamuusikud on aga tänapäeval Hiiu kandle omaks võtnud.

Kui Bergelt sai tuttavaks Eestirootslaste Kultuuri Seltsi aktivisti Ain Sarvega, kinkis rootslane eesti rahvamuusikule kaks enda tehtud Hiiu kannelt, kolmanda pilli kinkis teine meister Rootsis (arvatavasti Österberg). Need pillid laenati Raivo Sildojale (tol ajal Viljandis). Temast sai Eesti peamine Hiiu kandle meister ja tuntud mängija. Tema abikaasa Krista Sildoja on rahvamuusika uurija ja Hiiu kandle õpetaja, ka suviti Vormsi õpitoas, kus osaleb paar-kolmkümmend mängijat mitmest riigist. Mitmepäevased kursused said alguse Janne Suitsu korraldatud rahvusvahelistest konverentsidest (Vormsil 2005 ja Viljandis 2008). Suits kirjutas oma magistritöö talharpa mängutehnika ja traditsiooni taastamisest (2010) Norras. Teiseks Hiiu kandle õpistute korraldajaks sai eesti ja rannarootsi päritoluga Sofia Joons, kes elas Eestis 19 aastat, õppis muuseas Viljandi Kultuuriakadeemias ja töötas lõpuks August Pulsti õpistu juhatajana Pärimusmuusika Keskuses Viljandis. Joons ja Suits korraldasid dokumentaalfilmi "Talharpa" (2009) tegemist, mis näitab Hiiu kandle ja samalaadsete pillide mängijaid mitmelt maalt. Viimasel ajal on Vormsiga seotud kohalikud mängijad hakanud suuremat rolli mängima Hullo õpistute korraldamises. Vormsil on käinud õpetamas ka Soomest jouhikko ja Rootsist talharpa mängijaid.

Eriti tähtsat rolli on mänginud Rauno Nieminen, kes on välja andnud kolm raamatut soome ja eesti traditsioonide kohta (mängis 1979. aastast alates rahvamuusikaansamblis Primo - Primitive Music Orchestra koos kanteleekspertide 
Hannu Saha ja Heikki Laitineniga). Oma raamatutega on ta teinud kergesti kättesaadavaks fotosid ja kirjeldusi vanadest pillidest ja mängijatest, noodistusi, helisalvestusi ja palju üksikasju Soomest, Karjalast, Eestist ja Rootsist korjatud muuseumieksemplaride ehituse kohta. Nieminen ise hakkas jouhikkoid meisterdama 1977. aastal ja teeb tänapäeval ka eesti pillide jäljendeid. Mängima õppis ta esialgu vanade raamatute ja helisalvestuste abil, aga 1981. aastal sai põhjalikult tutvuda Jouni Arjava pärimusliku mängustiiliga. Arjava oli kuulsa vana jouhikkomängija Pekka Lambergi (1863-1929) pojapoeg. Niemineniga tutvus juba 1980. aastatel Eestist Helsingisse Sibeliuse Akadeemiasse läinud muusikaõpilane ja -õpetaja Anneli Kont-Rahtola, kes õppis jouhikkol mängima Niemineni endise õpilase Maija Karhineni käe all ja aitas pärast Ain Sarvega korraldada Hiiu kandle õpetamist Viljandi rahvamuusika kursuste kavas.

Ilma Niemineni ja Bergelti abita poleks Hiiu kandle õpetamine olnud nii pärimuspõhine nagu ta on. Kui Toivo Luhats hakkas 1960. aastatel proovima Hiiu kannelt mängida, puudusid andmed vana mängustiili kohta. Ta otsustas, et keeled võiksid olla häälestatud nagu viiulil, aga peegelpildis. Tegelikult on olemas üks vana filmijupp Mart Kaaseni mängust (Eesti Filmi Andmebaas 1938), aga see polnud Luhatsi uurimise ajal nii kergesti leitav kui see on tänapäeval arvutivõrgu kaudu. Enne kui saadi selge pilt ammusest mängustiilist, hakkasid mõned viiulimängu kogemustega eesti mängijad vajutama ka sõrmede sisekülgedega vastu esimest keelt, aga ikka sõrmeselgadega vastu teist keelt. Eelis sellega on, et nii saab kiiremini mängida kahel keelel ja pole karta, et mõni sõrmeots läheb kogemata esimese keele vastu, kui liigub selle alt läbi. Siiski näidatakse traditsioonilist mängutehnikat, nii et uued mängijad saavad ise valida, kuidas nad vastu keeli vajutavad.

\section{Tähtsad tegurid}

Ei saa olla lihtsalt kokkusattumus, et siin käsitletud kolme rahvapilli taandumine algas samal ajal (19. sajandi lõpul) ja kõigi tagasitulek toimus samal ajal (20. sajandi lõpul), et huvi rahvapillide vastu on nüüd tõusmas nii Eestis kui ka väliseestlaste seas, või et sarnased protsessid on ilmnenud teistes arenenud tööstusriikides. Paistab, et samasugused tegurid on nii pillide taandumise kui ka nende tagasituleku taga. Need tegurid on põhilised muutused, mis kaasnevad tööstusriikide arenguga: linnastumine, tehnoloogia areng ja rahvusvahelised kontaktid. Nende vastuolulised mõjud olenevad ühiskonna arengujärgust.

Tööstusriigi algfaasis kogunevad inimesed maalt linnadesse uute vabrikute ja kontorite juurde, otsides paremaid võimalusi rahateenimiseks, oskuste rakendamiseks, huvitavate elamuste ja vabama õhkkonna kogemiseks. Linnas on 
tihedaid kokkupuuteid teistsuguste inimestega, kuna toimub spetsialiseerimine, rahvusrühmade segunemine, subkultuuride tekkimine jne. Nähakse, et saab elada, töötada ja lõbutseda teistmoodi kui vanemad põlvkonnad tegid omal ajal, ja traditsioonide austamine kahaneb, muuseas ka rahvamuusika valdkonnas. Selle asemel, et ise nii palju teha, hakkavad inimesed ostma rohkem esemeid ja teenuseid, mida teised pakuvad. Vabrikud-töökojad toodavad muuseas ka uusi muusikariistu ja nende ostmine on suhteliselt odav ning palju kergem kui oma pilli meisterdamine. Massiliselt toodetakse selliseid muusikariistu, mille levitamine on tulutoovam, ning see tähendab standardiseeritud kuju ja stabiilse häälestusega pille, mis sobivad muuseas orkestrites mängimiseks ega ole seotud ainult piiratud ringkonna (nt ühe rahvusrühma või maakonna) pärimusega. Linnakorterites on ruumipuudus suurem kui eramajades, nii et inimestel on raskem kodus koguda tööriistu ja seadmeid pillide tegemiseks. Kitsas eluruumis on torupilliga eriline probleem, kuna selle valju pilli harjutamine võib segada naabreid. Linnades kalduvad inimesed hindama moodsaid, tsiviliseeritud maiguga pille ja alavääristama vanamoodsaid. Äsja linna kolinud inimesed ei ela tavaliselt koos oma vanemate ja vanavanematega või nende läheduses, sellega kaovad võimalused õppida kogenud pillimeistrite ja mängijate käe all.

Tehnoloogia areng toob uued masinad ning transpordi-ja sidevahendid, mis võimaldavad ülalmainitud standardiseeritud pillide massilist tootmist, reklaamimist ja levitamist. Raadio kaudu jõuavad linnamuusikute esinemised ja helisalvestused maainimeste kõrvu. Isolatsiooni kadumisega on traditsioonidel raskem püsida. Järjest efektiivsemate seadmete tekkimisega harjuvad inimesed mõttega, et uued asjad on paremad. Masinatega töötanud inimene hakkab mõtlema ratsionaalsemalt, sest töökäik on ennustatavam ja kontrollitavam. Looduses töötav inimene, kelle käekäik oleneb ilmastikust ja loomade-taimede kahjuritest ning haigustest, tunneb ennast haavatavamana ja otsib pigem lohutust rituaalides, võimalikult vana rahvapilli saatel. Linlasel on vabam valik muusikariista suhtes, kui pillimäng pole vanade uskumustega seotud.

Kuna tööstusriik on seotud maailmaturuga, tekivad tihedad kontaktid välismaaga. Nende kontaktidega kaasnevad uued mõtteviisid, kombed ja maitsed. Muusikat saab kergesti laenata teisest kultuurist, sest pole isegi vaja võõrkeeleoskust, et jälgida meloodiat, rütmi, helilaadi ja pillihäält. Tekib uudishimu uute pilliliikide vastu, muusikamaitse muutub ja inimesed hakkavad eelistama kromaatilisi ja laiema noodiulatusega viise, duurivahetusi, täpsemat häälestust ja muud, mida on raske saavutada vanadel rahvapillidel.

Miks siis hakkas huvi vanade rahvapillide vastu jälle kasvama? Üks põhjus: needsamad kontaktid võimaldavad andmete jagamist laiema asjatundjate ringkonnaga. Rahvusvahelised konverentsid, festivalid, õpireisid, töökogemused, meilivahetused jne on ergutanud rahvapillihuvilisi uurima oma pärimust, 
võrdlema seda teiste kultuuride traditsioonidega ning proovima mängutehnikaid ja pillitegemisnippe, mis on ehk kaduma läinud. Võõramaa muuseumides, arhiivides ja raamatukogudes võib leiduda Eestist pärit pille, helisalvestusi, filmilõike, fotosid, noodistusi, märkmeid ja väljaandeid, mis on kasulikud meie traditsioonide selgitamiseks.

Viimase aja leiutised kergendavad sellist infovahetust. Kiiresti ja laialt saab meilitsi jagada avastusi, nõuandeid, arvamusi, helifaile, videolõike, skaneeritud fotosid, artikleid, pillijoonistusi jne. Arvutivõrgu kaudu saab üksik pillihuviline kergesti otsida selliseid vahendeid isegi täitsa võõrastelt inimestelt ja senitundmata asutustelt, vaadata muuseumieksemplare, õppida uusi mänguvõtteid. Moodsate häälemõõtmisaparaatidega saavad mängijad oma pillid ruttu ja täpselt häälde panna, nii et rahvapillid saavad meeldivama kõla harjutustel, kontsertidel ja salvestustel.

Linlastel on kergem kokku saada teiste mängijatega, nendega koos harjutada ja moodustada ansambleid. Linnades paiknevad muuseumid, arhiivid, raamatukogud, muusikakoolid ja teised asutused, mis on traditsioonide taaselustamisel väga olulised. Linnades on kergem otsida kauplustest vahendeid pillitegemiseks, mängutehnika õppimiseks, salvestamiseks jne. Linnades on rohkesti esinemisvõimalusi - festivalidel, kontserdilavadel, rahvatantsuklubides, seltside üritustel jne.

Inimesed on nüüd harjunud nende moodsate pillidega, mis asendasid vanemaid rahvapille. Teatud määral on nad nendest isegi tüdinenud või saavad vähemalt aru, et viiuleid, lõõtspille, kitarre jne leidub igal pool. Tööstusriigid arenevad enamvähem samas suunas, kui räägime pilvelõhkujatest, autodest, arvutitest, kiirtoidurestoranidest, televisioonisaadetest ja paljust muust. Sellise homogeensuse või üksluisusega tekib vastureaktsioon, kus inimesed otsivad ja naudivad eksootikat, ainulaadsust, omapära ja vaheldust. Selleks sobib vana rahvamuusika väga hästi, sest vanasti olid rahvuste ja isegi maakondade erinevused suuremad pillide, mängutehnika ja viisitüüpide suhtes. Eriti vähemusrahvad (nagu eestlased), kes on olnud mitme suure riigi valduses (Venemaa/ Nõukogude Liit, Ameerika Ühendriigid, Kanada, Austraalia), vajavad midagi, mis eristab neid suurest rahvamassist, äratab tähelepanu nende päritolu suhtes, tekitab muulaste seas huvi ja isegi estofiilsust. See innustab oma noori esivanemate kultuuripärandit uurima ja austama.

\section{Lõppsõna}

Traditsioonid ei saa säilida, kui noored ei ole uudishimulikud oma pärandi suhtes ja uhked oma päritolu üle. Siinjuures pole paremat näidet rahvapillide sobivusest, kui Eesti populaarne ja rahvusvaheliselt läbi löönud folkmetal an- 
sambel Metsatöll. Selles mängib rahvamuusik Lauri Õunapuu kitarristist ja trummarist hevirokkarite kõrval kannelt, torupilli ja Hiiu kannelt ning laulab regilaulu stiilis.

Kindlasti aitab sellele kaasa olukord, et ollakse valmis traditsioonidest loobuma vähemalt ühes punktis. Tänapäeval leidub mängijate, õpetajate, uurijate ja isegi pillitegijate seas rohkesti naisi. Ainuüksi sellega on tegijate arv kahekordistunud.

Eestis on õnneks olukord vanade rahvapillide traditsioonide säilitamiseks praegu üsna soodne. Riigiasutused (nt muusikakoolid, muuseumid), mittetulundusühingud (festivalide korraldajad, teabekogud, sihtasutused), erafirmad (heliplaatide tootjad ja kontsertide korraldajad) ja üksikettevõtjad (pillimeistrid) võtavad asja tõsiselt, töötavad koos, otsivad kestvaid lahendusi, mis kindlustavad rahvamuusikute järelkasvu. Väliseestlaste seas on olukord murettekitavam, sest tegelasi ja toetavaid asutusi on vähem. Aga nii kaua kui Eestis rahvapille säilitatakse, toimub see tõenäoliselt mingil määral ka välismaal, isegi ja eriti moodsa ühiskonnakorra oludes.

\section{Kommentaar}

Artikkel on edasiarendus 14. septembril 2015 Tallinna Ülikooli rahvusvahelisel konverentsil "Eesti kultuuri suurpeod maailmapärandis" peetud ettekandest.

\section{Allikad}

Eesti Filmi Andmebaas 1938. Tantsulugusid vanadelt pillimeestelt. Eesti Kultuurfilmi ringvaade 41: 4/4 (https://www.efis.ee/et/filmiliigid/film/id/1201/videoklipid - 29. märts 2016).

Eesti Rahvusringhäälingu arhiiv 1989. Pillimeister: Aksel Tähnas. Režissöör Georg Jegorov. Eesti Televisiooni saade, 5. mai (https://arhiiv.err.ee/vaata/pillimeister-akseltahnas - 29. märts 2016).

Eesti Rahvusringhäälingu arhiiv 1991. Pillimeister Andres Peekna. Režissöör Georg Jegorov. Eesti Televisiooni saade, 25. jaanuar (https://arhiiv.err.ee/vaata/pillimeisterandres-peekna - 29. märts 2016).

ERM - Eesti Rahva Muuseum

Kann, Tuule 2016. Elektrooniline kiri, 10. märts. Kiri autori valduses.

Karras, Pille 2016. Elektrooniline kiri, 4. jaanuar. Kiri autori valduses.

Leydon, Rita Flodén 2006. Styrbjörn Bergelt. Swedish Folk Music Treasures. Videofilm, DVD. Lahaska PA, USA: Leydon Grafix.

Mehnetsov, Anatoli salvestatud guslimängu näited: https://www.youtube.com/watch?v= JyCZGYNNFbA\&nohtml5=Falseeni N. A. Rimskogo-Korsakova (7. aprill 2016); https:// 
www.youtube.com/watch?v=kWe1PWoXdn8\&nohtml5=False (7. aprill 2016); https:// www.youtube.com/watch?v=Z8UUiIIhPyM\&nohtml5=False (7. aprill 2016); https:// www.youtube.com/watch?v=CFJeU4vpnlU\&nohtml5=False (7. aprill 2016); https:// www.youtube.com/watch?v=BI0KXv5tgy4\&nohtml5=False (7. aprill 2017).

Peekna, Andres 1995. Küsitlus, autori märkmed. Indianapolis, 25-26. veebruaril, lisaga täiendatud 10. juunil 1999.

Rahkonen, Carl 2015. Elektrooniline kiri, 14. juuli. Kiri autori valduses.

Raudkivi, Valter 1973a. Kandle valmistamisest. Kirja koopia autori valduses, originaal on tema tütrepoja Verner Walter Esopi valduses. Baltimore, 5. juulil.

Raudkivi, Valter 1973b. Kuidas ma valmistasin esimese kandle. Kirja koopia autori valduses, originaal on tema tütrepoja Verner Walter Esopi valduses. Baltimore, 5. juulil.

Raudkivi, Valter 1973c. Kuda ma õppisin kannelt mängima. Kirja koopia autori valduses, originaal on tema tütrepoja Verner Walter Esopi valduses. Joppatowne (Baltimore), 19. septembril.

Taul, Ants \& Taul, Triinu mängunäide: https://www.youtube.com/watch?v=ze-7UPLGIYU (23. märts 2016).

Westerblom, Hans \& Arsenault, Barbara \& Eichenbaum, Eva 1987. Eesti rahvapillid. Videofilm Lydia Vohu-Viksteni kommentaaridega. Toronto: Seven Arts Production.

\section{Kirjandus}

Allmo, Per-Ulf 1990. Säckpipan i Norden. Från änglars musik till Djävulens blåsbälg. Musikmuséets skrifter 18. Stockholm: AllWin.

Andersson, Otto Emanuel 1923. Stråkharpan: En studie i nordisk instrumenthistoria. Helsingfors: H. Schildts.

Andersson, Otto 1930. The Bowed Harp: A Study in the History of Early Musical Instruments. London: William Reeves.

Andersson, Otto 1961. Bröllopsmusik på säckpipa. Studier tillägnade Carl-Allan Moberg. Stockholm: Svensk tidskrift för musikforskning 43, lk 17-36.

Arndt, Johann Gottfried 1747. Der Liefländischen Chronik Erster Theil von Liefland unter seinen ersten Bischöfen, welcher die alte Geschichte der Russen, Deutschen, Schweden, Dänen, Esthen, Liven, Letten, Litthauer, Curen und Semgallen erleutert. Oder die Origines Livoniae sacrae et civilis, wie solche der königl. Hofrath und Bibliothekarius zu Hannover Herr Johann Daniel Gruber, aus einem alten Manuscript Lateinisch herausgegeben und mit gelehrten Noten versehen, nunmehro aber aus andern Handschriften ergänzet, mit der nöthigen Anzeige der verschiedenen Lesearten wie auch mit kurzen Anmerkungen begleitet und ins Deutsche übersetzet von Johann Gottfried Arndt, der Schule zu Arensburg auf Oesel Rector. Halle-Magdeburg: Joh. Justinus Gebauer (http:// hdl.handle.net/10062/30456 - 29. märts 2016).

Arro, Elmar 1931. Zum Problem der Kannel. Õpetatud Eesti Seltsi aastaraamat 1929. Tartu, lk 158-190. 
Baines, Anthony 1960. Bagpipes. Occasional Papers on Technology 9. Pitt Rivers Museum, University of Oxford.

Bergelt, Styrbjörn 1979. Stråkharpans spelteknik. Riksinventeringens rapport 23. Stockholm: Musikhistoriska Museet.

Böning (Nõlvak), Astrid 2002. Vassili Sepa kandle mängutehnika kirjeldus. Rahvamuusika õppetooli diplomitöö. Viljandi Kultuurikolledž.

Dahlblom, Kari 2011. Keski-Suomen kantele. Saarijärvi: Saarijärven Offset Oy.

Eisen, Matthias Johann \& Krohn, Kaarle \& Alava, Vihtori \& Kallas, Oskar \& Anderson, Walter \& Grünthal, Villem (toim) 1926. Eesti rahvalaulud: dr. Jakob Hurda ja teiste kogust I. Tartu: Eesti Kirjanduse Selts.

Faehlmann, Fr. R. 1848. Bries des Hrn. Dr. Fählmenn in Dorpat. Boecler, Johann Wolfgang [Johann Forselius]. Der Einfältigen Ehsten Abergläubische Gebräuche, Weisen und Gewonheiten. Ärakiri raamatus Scriptores rerum Livonicarum. Sammlung der wichtigsten Chroniken und Geschichtstenkmale von Liv-, Ehst-und Kurland, in genauem Wiederabdrucke. II. Riga: Franzen, lk 681-686.

Haas, Ain 2001. Intercultural Contact and the Evolution of the Baltic Psaltery. Journal of Baltic Studies 23 (3), lk 209-250 (doi: 10.1080/01629770100000071).

Haas, Ain 2009. Origins of Latvian and Estonian Playing Styles in the Baltic Psaltery Revival. Musiikin suunta 1. Helsinki: Suomen etnomusikologinen seura, lk 23-41.

Hedman, Jörgen 2002. Djävulsharpan och helvetessäcken: Några reflektioner kring de unika estlandssvenska folkmusikinstrumenten. Kustbon 59 (4), detsember. Stockholm: Svenska Odlingens Vänner, lk 4-7.

Hoppe, Göran 2001-2002. Kring frågan om estlandssvenskarnas äldsta historia. Kustbon Stockholm: Svenska Odlingens Vänner. 1. osa 58 (3), september 2001, lk 3, 5, 10-11, 27; 2. osa 58 (4), detsember 2001, lk 5-7, 21; 3. osa 59 (1), märts 2002, lk 1, 8, 12-13.

Itkonen, Erkki \& Kulonen, Ulla-Maija (toim) 1992. Suomen sanojen alkuperä. Etymologinen sanakirja I. Helsinki: Suomalaisen Kirjallisuuden Seura.

Jansons, Andrejs (koost) 1965. Koklešana. Toronto: Greenwood Printers.

Joons, Sofia \& Tamm [Suits], Janne 2009. Talharpa: Hiiu kannel ja selle sugulaspillid. Film, DVD. Viljandi: Pärimusmuusika Keskus.

Karras, Pille 2010. Väikekandle mänguvõtete õpetamine klassitunnis. Urbel, Liivi \& Raudsepp, Inge \& Köster, Anneli (koost). Kunst [võrguteavik]. Valdkonnaraamat põhikooliõpetajale. Tallinn: Riiklik Eksami- ja Kvalifikatsioonikeskus (http://www.oppekava. ee/images/4/40/Väikekandle_õpetamine.pdf - 30. märts 2016).

Karras, Pille 2011. Diatoonilise kandle repertuaari seadmine kromaatilisele kandlele Joosep Kotka ja Alfred Kuusi repertuaari põhjal. Loomingulise magistrieksami kirjalik osa. Viljandi: Eesti Muusika ja Teatriakadeemia TÜ Viljandi Kultuuriakadeemia (http:// dspace.ut.ee/bitstream/handle/10062/17698/Pille_Karras_magistritoo.pdf?sequence=1 30. märts 2016).

Kiviberg, Ando 1994. Eesti torupilli langus ja taassünd. Diplomitöö. Viljandi: Viljandi Kultuurikolledž. 
Kuus, Alfred 1974. Juhiseid kandlemängu õppijaile. Käsikiri. Toronto.

Laitinen, Heikki \& Hannu Saha 1988. A Guide to Five-String Kantele Playing. Kansanmusiikki-instituutin julkaisuja 28. Kaustinen: Kansanmuusiikki-instituutti.

Leichter, Karl 1982. Torupill - eestlaste lemmikpill. Leichter, Karl (autor) \& Jürisson, Johannes (koost). Valik artikleid. Tallinn: Eesti Raamat, lk 125-141.

Leisiö, Timo 2014. Bagpipe and pilli in Estonia and Finland: An Etymological Approach. Working Papers of the Third International Congress of Belarusian Studies [2013] (http:// icbs.palityka.org/wp-content/uploads/2014/09/09-12_Leisio.pdf - 7. aprill 2016).

Leisiö, Timo \& Tainio, Juha 1988. "Pisti pillit säkkihinsä”. Ajatuksia säkkipillistä Suomenlahden rantamailla. Tampere: University of Tampere, Department of Folk Tradition, Articles \& Reprints 13.

Lindström, Anders 1990 [1967]. Mas-Billas Harpa. Lagman, Edvin (toim). Estlandssvenskar berättar: Dialekt texter med översättning och kommentar. En bok om Estlands svenskar 3B. Stockholm: Kulturföreningen Svenska Odlingens Vänner, lk 86-90. [Vormsi rootsi murdekeeles 1967. Maas-Billas harpa. Kustbon 3. september, lk 7].

Loit, Erich 1976. Muusikainstrumendid ja orkestrid. Tallinn: Eesti Raamat.

Luhats, Toivo 2007. Päkarauakandle mänguõpetus. Tallinn: Eesti Folkloori Selts. Mehnetsov 2006 = Mehknetsov, A[natolii] M. 2006. Russkie gusli i gucel'naja igra. Issledovanie i materialy. Sankt-Peterburg: Fol'klorno-etnograficheskii tsentr.

Mehnetsov 2009 = Mehknetsov, A[natolii] M. 2009. Russkie gusli i gucel'naja igra . Sankt-Peterburg: Fol'klorno-etnograficheskii tsentr, Sankt-Peterburgskoi gosudarstvennoi konservatorii.

Metsmägi, Iris \& Sedrik, Meeli \& Soosaar, Sven-Erik (koost ja toim) 2012. Eesti etümoloogiasõnaraamat. Tallinn: Eesti Keele Sihtasutus.

Nieminen, Rauno 1984. Jouhikko. Kansanmusiikki-instituutin julkaisuja 13. Kaustinen: Kansanmusiikki-instituutti.

Nieminen, Rauno 2006. Jouhikko: The Bowed Lyre. Kansanmusiikki-instituutin julkaisuja 61. Kaustinen [täiendatud versioon, helisalvestustega].

Nieminen, Rauno 2008. Soitinten tutkiminen rakentamalla: Esimerkkinä jouhikko. Sibelius-Akatemian kansanmusiikin osaston julkaisuja 12. Helsinki.

Nyberg, Bo 1986. Namensläika: Om bröllopsmelodier från Rågöarna. Uppsala Ülikool.

Nyberg, Bo 1990. Drompip, drummpipa, säckepip: Säckpipan hos estlands-svenskarna. Allmo, Per-Ulf. Säckpipan i Norden. Stockholm: AllWin, lk 236-281.

Olearius, Adam 1996 [1656]. Täiendatud uus reisikiri Moskoovia ja Pärsia teekonna kohta, mis toimunud Holsteini saatkonna lähetamisel Vene tsaari ja Pärsia kuninga juurde. Tallinn: Olion.

Povetkin, Vladimir I. 1989. O proiskhozhdenii guslei s igrovym oknom: Iz opyta vosstanovitel'nykh rabot. Fedorov-Davydov, German \& Rybina, Elena \& Khoroshev, Aleksandr (koost). Istoriia i kul'tura drevnerusskogo goroda. Moskva: Izd. Moskovskogo universiteta, lk 116-127. 
Povetkin, Vladimir 2007. Musical Instruments. Brisbane, Mark \& Hather, Jon (toim). Wood Use in Medieval Novgorod. The Archaeology of Medieval Novgorod. Oxford: Oxbow, lk 360-381.

Priedīte, Īrisa 1988. Tautas mūzikas instrumenti. Latvijas Etnogrāfiskais Brīvdabas Muzejs. Riga: Avots.

Pulst, August 1973. Torupilli Juss ja teised. Kultuur ja Elu 7, lk 33-36; nr 8, lk 20-25; nr 9, lk 24-26.

Rahkonen, Carl 1994. The Estonian Kannel in Baltimore. Ettekanne konverentsil Second International Symposium of Kankles Researchers, Vilnius, 16. nov.

Rannap, Heino 1972. Muusika eesti perekonnas ja rahvakoolis. Tallinn: Eesti Raamat.

Rehnberg, Mats 1943. Säckpipan i Sverige. Nordiska Museets Handlingar 18. Stockholm.

Reier, Aime 2014. Abiks väikekandle õppijaile. Põltsamaa: Tartu Ülikooli Viljandi Kultuuriakadeemia.

Reinholdson, Mattias 2002. Svenskar på Nuckö redan på 1100-talet. Kustbon 59 (3). Stockholm: Svenska Odlingens Vänner, lk 4-6.

Russow, Balthasar 1967 [1584]. Liivimaa kroonika. Tõlkinud Dagmar \& Hermann Stock. Stockholm: Vaba Eesti.

Rüütel, Ingrid 2012. Eesti uuema rahvalaulu kujunemine. Tartu: Eesti Kirjandusmuuseumi Teaduskirjastus.

Saha, Hannu 1986. Kymmenkielisen kanteleen opas. Kansanmusiikki-instituutin julkaisuja 21. Kaustinen: Kansanmusiikki-instituutti.

Sildoja, Krista 2014. Äratusmäng uinuvale rahvamuusikale: August Pulsti mälestusi. Tallinn: Eesti Teatri- ja Muusikamuuseum.

Suits, Janne 2010. Talharpa mängutehnika ja traditsiooni taastamine. Magistritöö. Rauland: Raulandi Rahvakultuuri Instituut.

Suurlaht, Helle 2004. Väikekannelde meisterdamine aastatel 1970-2003. Kursusetöö. Viljandi: Tartu Ülikooli Viljandi Kultuuriakadeemia.

Söderbäck, Per 1940. Rågöborna. Nordiska Muséets Handlingar 13. Stockholm.

Sööt, Jaan (koostaja) 1990. Kuuekeelne kannel. Tartu: Eesti Rahva Muuseum.

Tampere, Herbert 1975. Eesti rahvapillid ja rahvatantsud. Tallinn: Eesti Raamat.

Tampere, Herbert 1999. Eesti rahvaviiside antoloogia. Tallinn: Eesti Keele Instituut.

Tëmkin, Ilya 2004. The Evolution of the Baltic Psaltery: A Case for Phylorganology. The Galpin Society Journal 57 (May), lk 219-230 (http://torban.org/docs/Temkin2004. pdf - 30. märts 2016).

Tõnurist, Igor 1976. The Estonian Bagpipe. Maeyer, Rene de (toim). The Bagpipes in Europe I. The Brussels Museum of Musical Instruments Bulletin 6: 1/2, lk 47-54.

Tõnurist, Igor 1977a. Kannel Vepsamaast Setumaani. Rüütel, Ingrid (koost). Soome-ugri rahvaste muusikapärandist. Tallinn: Eesti Raamat, lk 149-182.

Tõnurist, Igor 1977b. Torupill Lääne-Ingeris. Etnograafiamuuseumi aastaraamat 30. Tallinn: Valgus, lk 212-219. 
Tõnurist, Igor 1998. Muusika ja tants. Viires, Ants \& Vunder, Elle (koost, toim). Eesti rahvakultuur. Tallinn: Eesti Entsüklopeediakirjastus, lk 459-483.

Tõnurist, Igor 2005. Päkarauakandle mängutraditsioon vajab elustamist. Teater, Muusika, Kino 11, lk 104-109 (http://www.temuki.ee/arhiiv/2005/11/lugu14.pdf - 30. märts 2016).

Tõnurist, Igor (koost ja toim) 2008. Eesti rahvapille. Tallinn: Tallinna Raamatutrükikoda.

Valk, Katrin 2005. Labaga kannel Setumaal 20. sajandi algul: mängutraditsiooni ja pillilugude analü̈̈s. Bakalaureusetöö. Tartu: Tartu Ülikooli kirjanduse ja rahvaluule osakond (http://kannel.rahvamuusika.ee/sisu/310_636_243_Uurimus_pdf_kujul_loe_siin. pdf - 30. märts 2016).

Viitso, Tiit-Rein \& Ernštreits, Valts 2013. Līvõkīel-ēstikīel-leţkīel sõnarontõz. Tartu \& Riga: Līvõ Kultūr Sidām, Tartu Ülikool \& Latvian Language Agency (http://www.murre. ut.ee/liivi/index.html - 30. märts 2016).

Västrik, Ergo-Hart 1998. Kombest valmistada kalendritähtpäevadel inimesena riietatud õlgkuju. Kalda, Mare \& Kõiva, Mare (toim). Artikleid usundi- ja kombeloost. Sator 1. Tartu: Eesti Keele Instituut, lk 157-189 (http://www.folklore.ee/rl/pubte/ee/sator/sator1/ ergo.html - 30. märts 2016).

Veske, Mihkel 1877. Bericht über die Ergebnisse einer Reise durch das Estenland im Sommer 1875. Verhandlungen der gelehrten estnischen Gesellschaft 8: 3. Tartu.

Veske, Mihkel 1879. Eesti rahvalaulud. Esimene anne. Rahwa suust korjanud ja wälja andnud Dr. M. Weske. Tartu: Schnakenburg.

\section{Summary}

\section{Preservation of folk instrument heritage in Estonia and abroad}

\section{Ain Haas}

Keywords: bagpipe, bowed lyre, Estonian kannel

By the middle of the 20th century, old folk musical instruments had disappeared from Estonian culture. Musicians played modern internationally widespread instruments, especially the accordion and the guitar. The article discusses the return of old folk musical instruments, especially the Estonian kannel (plucked Baltic psaltery), bagpipe, and bowed lyre. The revival of these traditions has been more marked in Estonia, due to the contribution from music schools and museums; yet similar processes can also be detected among diaspora Estonians. Initiators and key persons enthused by the lost culture of their ancestors have played an important role on both sides. Interest in these old instruments is a manifestation of people's resistance to the homogeneity of the modern society.

Urbanization, international contacts, and modern technology led to the fading popularity of folk music in the past century, yet the same factors have recently proven important in reviving traditions. 